\title{
4 \\ TRIBUTAÇÃO SOBRE A RENDA: \\ PRINCÍPIO DA CAPACIDADE CONTRIBUTIVA \\ E O LIMITE DE ISENÇÃO DO IRPF
}

Daniela Ovídio Fernandes

\section{INTRODUÇÃO}

O Estado é uma sociedade politicamente organizada que serve à representação um povo, assume compromissos e tem por obrigação o oferecimento de garantias mínimas estabelecidas pela Constituição Federal (CF) aos verdadeiros titulares do poder. Para que esta finalidade seja cumprida, torna-se necessário o estabelecimento de fontes, ou entradas, para que seja possível custear todos aqueles gastos consequentes das obrigações por ele assumidas. As entradas são consideradas originárias quando são frutos da utilização dos bens que o próprio Estado possui, e são chamadas derivadas as oriundas das prestações patrimoniais impostas aos cidadãos. $\mathrm{O}$ montante obtido por meio de ambas deve ser suficiente para o custeio das despesas, pois do contrário, há o surgimento da dívida pública.

A fim de regular essas entradas derivadas é que a CF estabelece que a manutenção das finanças públicas se dará em parte por meio da cobrança de tributos, conferindo aos entes públicos o poder de instituir tributos, cada qual delimitado por sua competência, para que desta forma possam auferir receitas suficientes ao fornecimento de bens e serviços essenciais à população, como o acesso à educação, saúde, moradia, saneamento básico, obras de infraestrutura, dentre outros.

A Constituição estabelece em seu Título VI, "Da Tributação e do Orçamento", os princípios norteadores, as limitações do poder de tributar, a competência conferida a cada um dos entes públicos (União, Estados, Distrito Federal e Municípios) e as regras atinentes à repartição das receitas tributárias. O art. 145, da CF, 
•• Tributação, direitos fundamentais e desenvolvimento

institui que os entes terão a faculdade de instituir as diferentes espécies de tributos, ou seja, poderão impor aos cidadãos o pagamento de taxas e contribuições de melhorias, que são tributos vinculados a uma atividade estatal prestada ou colocados à disposição do contribuinte, conforme dispuser a lei; ou ainda, a cobrança de impostos, os quais não se vinculam a nenhuma prestação estatal, podendo ser cobrados a partir de sua instituição legal, devendo sempre que possível ter caráter pessoal e serem graduados segundo a capacidade econômica do contribuinte, conforme $₫ 1^{\circ}$, art. 145 , CF.

Também neste sentido podemos citar o Art. 16 do Código Tributário Nacional (CTN) que traz a definição da espécie tributária chamada Imposto da seguinte forma: "Imposto é o tributo cuja obrigação tem por fato gerador uma situação independentemente de qualquer atividade estatal específica, relativa ao contribuinte." Além disso, a CF, o CTN e a legislação ordinária faz a classificação dos impostos segundo critérios diferenciados, distinguindo-os e conferindo a cada um efeitos tributários próprios.

Os impostos são regidos pela Carta Magna nos arts. 153 e seguintes, merecendo destaque o instituído pelo inc. III deste mesmo artigo, cuja instituição compete à União, sobre renda e proventos de qualquer natureza, mais conhecido como Imposto de Renda, exigido tanto da pessoa física (IRPF), quanto da pessoa jurídica (IRPJ). Este será o tema do presente trabalho, em que serão abordadas diversas questôes atinentes ao Imposto de Renda, relacionando estudos que envolvam o Princípio da Capacidade Contributiva, que orienta o direito tributário, consagrado no art. 145, $\$ 1^{\circ}$, da Constituição Federal, com as normas relativas ao limite de isenção do Imposto de Renda instituído em face do contribuinte pessoa física, com o objetivo geral de discutir a relação entre tais aspectos e analisar as consequências que podem surgir da não obediência aos princípios fundadores da justiça fiscal.

O presente trabalho tem como objetivos específicos analisar o Princípio da Capacidade Contributiva de forma pormenorizada, associando-a tributação sobre a renda da pessoa física; analisar o Instituto do Imposto de Renda, definir o conceito de isenção, sua finalidade, os índices determinantes de seu valor, bem como a necessidade de correção e reajuste, por meio do qual se tornaria possível uma melhoria na distribuição da carga tributária imposta à população, e por fim, mostrar a repercussão do tema no cenário judicial brasileiro. Em sua elaboração, foi utilizado o método de revisão bibliográfica, também conhecido como revisão de literatura, cujo objetivo é analisar os estudos e pesquisas já realizados na área, ser- 
vindo de base a uma visão crítica sobre o tema, considerando a abordagem científica explorada por meio da publicação de livros, revistas, artigos acadêmicos, jurisprudência, dentre outros, que foram suficientes ao embasamento de uma conclusão inovadora.

\section{PRINCÍPIO DA CAPACIDADE CONTRIBUTIVA}

A Capacidade Contributiva é um dos mais relevantes princípios orientadores do direito tributário brasileiro, por meio do qual se busca estabelecer uma tributação justa e de acordo com os valores constitucionais, cujo fim principal é o desenvolvimento social e a redução das desigualdades econômicas, conforme se verá adiante.

\subsection{Conceito}

A fim de melhor compreender o propósito da presente pesquisa é importante que se inicie pelo próprio conceito do Princípio da Capacidade Contributiva, previsto no $\$ 1^{\circ}$ do Art. 145 da Carta Magna, Cap. I, que trata do Sistema Tributário Nacional, da seguinte forma: "Sempre que possível, os impostos terão caráter pessoal e serão graduados segundo a capacidade econômica do contribuinte, facultado à administração tributária, especialmente para conferir efetividade a esses objetivos, identificar, respeitados os direitos individuais e nos termos da lei, o patrimônio, os rendimentos e as atividades econômicas do contribuinte".

Conforme depreendido do texto constitucional, o Princípio da Capacidade Contributiva determina ao Estado que no momento de estabelecimento da obrigação tributária existe a necessidade de se observar a realidade social do sujeito passivo da relação. O legislador deve procurar fatos que demonstrem signo de riqueza, por esta razão faz referência à identificação do patrimônio e atividades econômicas do contribuinte. Isto ocorre porque o Princípio da Capacidade Contributiva tem por objetivo estabelecer que as despesas públicas sejam custeadas por todos os cidadãos, mas que sejam respeitados determinados parâmetros, devendo cada um contribuir com o Fisco de acordo com sua capacidade econômica, ou seja, o pagamento do imposto é determinado de acordo com o montante de renda auferido pelo sujeito, quanto maior a sua renda, mais alto será o imposto cobrado.

Ao respeitar o Princípio da Capacidade Contributiva, o Estado realiza uma tributação equilibrada e justa, pois faz a captação de parcelas do patrimônio suficiente 
•• Tributação, direitos fundamentais e desenvolvimento

para custear seus gastos e distribui a carga tributária de modo uniforme, atendendo também o princípio da igualdade. Paulo Barros de Carvalhos consagra o seguinte entendimento:

Da providência contida na escolha de eventos presuntivos de fortuna econômica decorre a possibilidade de o legislador, subsequentemente, distribuir a carga tributária de maneira equitativa, estabelecendo, proporcionadamente às dimensões do acontecimento, o grau de contribuição dos que dele participaram. (CARVALHOS, 2014, p. 175).

Por esta lógica de pensamento, a garantia da igualdade, consagrada no ordenamento jurídico brasileiro, é assegurada pelo Princípio da Capacidade Contributiva na medida em que a tributação não é aplicada com a cobrança de valores iguais, mas ao contrário, o cidadão contribui de acordo com a sua capacidade. Desta forma, a distribuição do encargo tributário é igualitária por causar impactos de mesmo nível na vida de pessoas com diferentes situaçôes econômicas. Seguindo esta linha de raciocínio, percebe-se que o tributo deverá respeitar determinados limites, como respeito ao mínimo existencial e vedação ao confisco, temas que serão abordados adiante, e deve incidir apenas onde há Capacidade Contributiva.

Importante lembrar que a expressão Capacidade Contributiva não pode ser confundida com Capacidade Tributária ou Capacidade Econômica. Segundo Edilson Pereira Nobre Júnior, a diferença entre as duas primeiras consiste no seguinte:

Capacidade tributária passiva quer dizer, então, a aptidão de alguém em ser sujeito passivo de uma relação obrigacional tributária. Não se confunde com capacidade contributiva. Enquanto a primeira representa uma noção estritamente jurídica, a segunda, ao invés, denota noção jurídico- econômica. (NOBRE JÚNIOR, 2001, p. 32).

Portanto, a Capacidade Tributária refere-se à capacidade que as pessoas naturais têm de se tornarem sujeito passivo de uma obrigação tributária, independentemente de sua capacidade civil, conforme art. 126, CTN. Ao passo que a Capacidade Econômica é traduzida como aptidão que todos os indivíduos, ou a grande maioria, têm de gerar renda, consumir ou formar patrimônio, ou seja, de produzir riqueza. Edilson Pereira Nobre Júnior também estabelece a distinção entre ambas:

Tampouco se deve confundir capacidade econômica com capacidade contributiva. A primeira, de ordem genérica, é aptidão que alguém, pessoa física ou jurídica, possui para produzir ou dispor de riqueza. Diversamente, a capacidade contributiva é específica, condizendo com a aptidão de determinado sujeito em poder ser obrigado a concorrer à satisfação das despesas públicas. (NOBRE JÚNIOR, 2001, p. 32). 
A partir desse esclarecimento, e sabendo que a Capacidade Contributiva é a aptidão que o indivíduo tem de contribuir com as despesas públicas, contribuindo para o pagamento dos tributos, entendemos que para que isto se torne possível é indispensável a referência à base econômica, afinal, a Capacidade Econômica é condição indispensável para que o sujeito apresente Capacidade Contributiva. Em síntese, podemos dizer que Capacidade Econômica e Capacidade Contributiva designam situações e condiçõos diferentes uma da outra, porém a primeira é condição essencial à segunda.

Insta ressaltar ainda que a leitura do texto constitucional, art. $145 . \$ 1^{\circ}$, em sua proposição "sempre que possível", embora pareça abordar uma contradição, assim não deve ser entendida. A expressão citada traz certa ambiguidade em relação à qual parte do dispositivo se refere. Enquanto há quem defenda que a referência se faz em relação à possibilidade de aplicação do princípio, há uma segunda corrente, que com muita coerência, aponta estar a proposição, na verdade, relacionada com o caráter do imposto. Esta última tem o entendimento baseado no sistema de valores e princípios adotados pelo ordenamento jurídico brasileiro, dentre eles o respeito à dignidade humana, à igualdade e à vedação ao confisco, e explica que como nem todos os princípios são de caráter pessoal, pois existem aqueles de caráter real, e que, portanto, a possibilidade abarcada pela expressão dependeria da condição do imposto, de ser ou não pessoal. Carrazza assim pontua:

O sentido desta norma jurídica é muito outro. Ela, segundo pensamos, assim deve ser interpretada: se for da índole do imposto, ele deverá obrigatoriamente ser graduado de acordo com a capacidade econômica do contribuinte. (CARRAZZA, 1991 apud NOBRE JÚNIOR, 2001, p. 66).

Logo, uma vez que o imposto é de caráter pessoal, não há que se falar em discricionariedade na aplicação do Princípio da Capacidade Contributiva, pois neste caso é absoluta, consagrando os ideais constitucionais.

\subsection{Aspectos históricos da capacidade contributiva}

A partir da definição do conceito, que inicia a compreensão sobre o tema, é válido levantar de forma breve alguns aspectos históricos do Princípio da Capacidade Contributiva, que permitirá aprofundar o conhecimento e fazer a devida contextualização.

Desde as primeiras civilizações pode-se notar uma relativa preocupação com a cobrança dos tributos, cada uma a seu modo peculiar, mas as sociedades antigas 
•• Tributação, direitos fundamentais e desenvolvimento

já buscavam exigir os tributos de forma justa. Observa-se que com o desenvolvimento e organização dos Estados, essa noção de justiça se transforma de acordo com as diferentes concepções sobre a forma de compreender a capacidade do indivíduo de contribuir. Nos tempos medievais, por exemplo, existiam os impostos justos, decorrentes do cometimento de pecado, eram penas, e por isso, considerados obrigatórios, e os injustos, que representavam arbitrariedade por parte dos soberanos, por conta disso eram combatidos. (NOBRE JÚNIOR, 2001, p. 17).

Com o passar dos séculos, em um cenário de menor intervenção do Estado, e consequentemente, de menores gastos, busca-se restringir a tributação, momento em que a Capacidade Contributiva é vista como uma forma de contraprestação aos serviços prestados pelo Estado; nesta visão, a Capacidade vinculava-se ao Princípio do Benefício, ou seja, o cidadão deveria contribuir com os gastos do Estado na proporção das vantagens oferecidas, os mais beneficiados, ou mais protegidos, deveriam contribuir mais. Este entendimento começa a perder força à medida que se torna difícil mensurar o quanto o Estado beneficiou um ou outro indivíduo, sendo outro fator importante o enfraquecimento do liberalismo. (ibidem, p. 19).

Neste segundo momento, o ideal de Capacidade Contributiva tem por objeto promover a igualdade econômica e social através da progressividade dos impostos. O ideal de justiça se faz presente aqui também, tendo em vista a busca pela repressão ao confisco e à intensa intervenção do Estado na liberdade e propriedade individuais. São exemplos de constituições que adotaram este entendimento a Italiana, Portuguesa, Espanhola, Argentina, entre outras. (NOBRE JÚNIOR, 2001, p. 20).

A consequência foi uma maior conscientização por parte dos cidadãos sobre a necessidade de se aplicar aos tributos o Princípio da Capacidade Contributiva, o que acabou por gerar na Declaração dos Direitos de 1789 uma garantia de que "os impostos deveriam ser suportados em proporção às possibilidades econômicas de cada um". No ano de 1929, a Capacidade Contributiva passou a ser a preocupação da Ciência Jurídica, deixando de ser objeto apenas da Ciência das Finanças. No ano de 1930, Grizotti desenvolve a Teoria da Utilidade que busca vincular o Princípio da Capacidade Contributiva e obrigação tributária, estabelecendo uma relação de causalidade entre elas, em que a obrigação teria como causa jurídica a Capacidade Contributiva, o que gerou uma mudança de perspectiva em relação ao Princípio da Capacidade Contributiva, até então entendida apenas como desdobramento do Princípio da Justiça, passa a ser um completo material ao princípio da igualdade. (CORDEIRO, 2006, p. 98). 
Atualmente, o Princípio da Capacidade Contributiva é discutido sob um novo viés, em que a Justiça Fiscal tem por objeto a garantia dos princípios do mínimo existencial e o da renda líquida disponível.

\subsection{Tratamento legal e aplicação no direito tributário brasileiro}

O ordenamento jurídico brasileiro sempre dispensou tratamento legal à capacidade do indivíduo de contribuir com os gastos públicos. Em determinados momentos históricos é possível observar uma maior preocupação por parte da legislação constituinte, ao passo que em outros, o assunto é abordado de forma mais atenuada, a depender do quadro político nacional.

A Constituição Imperial de 1824, predominantemente liberal, estabelecia que a contribuição do indivíduo às despesas do Estado deveria ser na proporção de seus haveres, e que ninguém poderia ser isento desta regra. Na Constituição de 1891 nota-se um caráter mais tímido ao abordar o assunto.

Ao passo que a próxima Carta Constitucional, de 1934, apresentou relativo avanço ao tratar do tema, determinando a progressividade dos impostos incidentes nas transmissões de bens por herança ou legado; proibindo a elevação de qualquer imposto acima dos vinte por cento do seu valor e atentando para que as multas de mora não ultrapassassem $10 \%$ do valor do imposto ou taxa, com fim de coibir um encargo injusto ao contribuinte.

A Constituição de 1937 não era expressa em seu texto quanto à adoção do Princípio da Capacidade Contributiva, porém, ao tratar da riqueza e prosperidade da nação (art. 135), afirmava serem dependentes da iniciativa individual e que, portanto, era necessário ter cuidado com os excessos fiscais para que não resultassem em prejuízo para o mecanismo de produção da iniciativa privada, o que demonstra preocupação em relação ao quantum de contribuição exercido pelo cidadão nos limites de suas possibilidades, evitando prejuízos aos cidadãos.

A retomada ao Estado democrático de Direito, com a Constituição de 1946, insculpe no art. 202 da Carta Magna o seguinte preceito: "Os tributos terão caráter pessoal sempre que isso for possível, e serão graduados conforme a capacidade econômica do contribuinte", declarando expressamente a adoção do princípio em um período no qual se busca garantir aos cidadãos os direitos que outrora lhes foram suspensos devido ao golpe do Estado Novo, apesar da intensa resistência quanto à inclusão do dispositivo, por parte de Mário Masagão, membro da Assembleia constituinte. 
-. Tributação, direitos fundamentais e desenvolvimento

No ano de 1965, é promulgada a Emenda Constitucional 18 que tratava, em linhas gerais, do Sistema Tributário Nacional, e revogou expressamente o art. 202 da Constituição vigente à época. A Constituição de 1967, bem como a Emenda 01/69, também permaneceu omissa, o que resultou em questionamentos se o Princípio da Capacidade Contributiva persistia no ordenamento jurídico ou se havia sido abolido. $\mathrm{O}$ argumento sustentado por parte da doutrina, que acreditava que o Princípio deveria ser assegurado, era o do regime democrático, fonte garantidora de outros princípios, como a igualdade, isonomia, vedação ao confisco, que por presunção lógica levaria à conclusão de prevalência da capacidade contributiva em consonância com os demais.

Por fim, é promulgada a Carta Magna de 1988, que idealiza dispositivo similar ao da Constituição de 1946. A discussão em torno do ideal de justiça tributária foi dominante durante o estabelecimento da assembleia constituinte, demonstrando grande preocupação no que diz respeito à justa distribuição do ônus tributário ao contribuinte, de modo que se pudesse estipular uma tributação mais regressiva no que toca aos setores de menor rendimento.

Importante anotar que à época em que foi promulgada a Constituição, momento no qual é implantado um sistema de governo absolutamente distinto do autoritarismo então vigente, em um contexto de busca veemente pela garantia de direitos através de um Estado Social e Democrático de Direito, muito se discutiu sobre a eficácia do Princípio da Capacidade Contributiva, qual seria seu alcance e seu papel diante do novo ordenamento jurídico brasileiro, tendo em vista a grande tendência de se compreender os princípios apenas como fontes supletivas do sistema. Entretanto, é de notório saber, igualmente, que hoje já não se sustenta tal dúvida, pois é uníssono o entendimento por parte da doutrina e jurisprudência de que os princípios, no geral, apresentam verdadeiro caráter normativo, e que uma vez violado um princípio, a ofensa alcança não apenas uma norma, mas todo o sistema. Neste sentido, muito bem pontua Editor ao dizer "Desse modo, se a capacidade contributiva é afirmada como um princípio, o que hoje é indiscutível, possui o condão de pauta ordenadora de todas as regras do sistema tributário vigente." (JÚNIOR, 2001, p. 59).

Não obstante a literalidade da atual Constituição (art. 145, $₫ 1^{\circ}$ ) ao referir-se apenas aos impostos quando do respeito à Capacidade Contributiva, há divergências doutrinárias no sentido de que não se deve negar aos demais tributos a aplicação do Princípio, ainda que de modo atenuado e com critérios distintos daqueles adotados nos impostos, pois o objetivo da arrecadação tributária, independente da 
espécie em questão, é arrecadar recursos particulares para manutenção do Estado, portanto, de acordo com este entendimento, seria necessário observar as possibilidades econômicas daqueles que são obrigados a contribuir. Porém de acordo com a Constituição, o Princípio não se aplica aos tributos vinculados, hipótese em que a cobrança do tributo vincula-se a uma contraprestação Estatal, e cujo objetivo é ressarcir o Poder Público dos gastos despendidos, como ocorre com as taxas e contribuiçôes de melhoria, nestes casos não haveria discricionariedade quanto à aplicação. A Capacidade respeitaria, segundo a vontade constitucional, somente a cobrança de impostos.

No que tange aos impostos, é necessário classificá-los a fim de circunscrever as hipóteses de obrigatoriedade da aplicação do Princípio da Capacidade Contributiva. O imposto pode ser direto, situação em que o ônus é suportado pelo próprio sujeito que pratica o fato gerador, assim sendo, não se questiona a aplicabilidade do Princípio, já que este se consubstancia em uma qualidade própria do contribuinte obrigado à prestação; e indireto, no qual existem duas figuras de sujeito: o contribuinte de direito, que pratica o fato gerador e recolhe o imposto, e o contribuinte de fato, sujeito seguinte da relação em cadeia, que é o responsável por suportar o encargo financeiro, neste caso, há uma reflexão quanto à possibilidade de se aferir a Capacidade Contributiva, visto que se torna difícil verificar as qualidades do verdadeiro sujeito passivo. Visando minimizar tal dificuldade, criou-se um mecanismo de graduação dos impostos indiretos que busca associá-los ao grau de essencialidade dos produtos tributados, vinculando a cobrança ao princípio da seletividade. Outra classificação dos impostos é a que os divide em impostos reais, leva em consideração os atributos da coisa, e os o impostos pessoais indubitavelmente estão submetidos à Capacidade Contributiva, em que se considera a progressividade das alíquotas, nas palavras de Júnior, "Nos impostos pessoais, a aplicação do princípio da capacidade contributiva se faz mediante sua graduação em correspondência com as condições pessoais do contribuinte." (NOBRE JÚNIOR, 2001, p. 68).

Ao passo que os impostos reais encontram uma maior resistência à adequação da Capacidade Contributiva, tendo em vista que neste caso leva-se consideração o bem e não a condição pessoal do contribuinte.

\subsection{Relação entre capacidade contributiva e demais princípios}

O Princípio da Capacidade Contributiva mantém íntima relação com outros princípios orientadores ordenamento jurídico pátrio. Dentre eles temos o princípio 
•• Tributação, direitos fundamentais e desenvolvimento

da igualdade, consagrado no art. $5^{\circ}$ da Constituição Federal, na medida em que afirma a igualdade de todos, garante que esta igualdade também deve prevalecer na tributação. Não se deve tratar de forma desigual aqueles que estão em situação semelhante, é neste sentindo que a Capacidade Contributiva deve ser garantidora de igualdade perante os contribuintes. Senão vejamos, o Estado precisa recolher tributos suficientes ao seu custeio e manutenção, porém a divisão deste ônus não pode causar impactos diferentes na situação econômica dos contribuintes, caso a divisão ocorra de modo que todos os cidadãos contribuam com valores iguais, não se poderá falar em igualdade, pois é apenas uma igualdade aparente, tendo em vista que a sociedade é formada por diferentes classes econômicas, e com isso a parcela mais abastada teria uma diminuição do seu patrimônio, enquanto que os demais não sofreriam alteração em sua riqueza. Stuart. Mill defende a igualdade na tributação da seguinte forma:

Por que motivo a igualdade deve ser a norma em matéria de tributação? Porque esta deve ser a norma em tudo aquilo que diz respeito às coisas referentes ao governo. Já que o governo não deve fazer nenhuma discriminação, de pessoas e classes quanto à força dos direitos que as pessoas têm em relação a ele, é preciso que qualquer sacrifício que exigir delas represente, na medida do possível o mesmo ônus para todas- sendo essa, importa notar, a maneira que, no conjunto, acarreta menos sacrifício. (MILL, 1983, apud HACK, 2014, p. 84).

A Capacidade Contributiva deve dar tratamento isonômico aos contribuintes, buscando consolidar o ideal de justiça, pois seu escopo é evitar que a tributação seja em igual valor e possibilitar que cada pessoa contribua de acordo com sua capacidade. Logo, em tributação, pode-se dizer que a igualdade se faz representar pela existência ou não da Capacidade Contributiva, de acordo com Hack, "A capacidade contributiva é a capacidade que alguém tem de contribuir para as despesas públicas. O tributo, portanto, só incide onde há capacidade contributiva." (HACK, 2014, p. 4).

A partir do princípio da igualdade, decorrem outros princípios, como o da proporcionalidade, seletividade e progressividade. O princípio da proporcionalidade determinada que o Estado deve exigir dos cidadãos com Capacidade Contributiva um valor que seja proporcional ao que ele apresenta e que se sobreponha à faixa mínima de subsistência. Esta regra torna-se evidente quando se trata do preceito constitucional de vedação ao confisco, é o que diz Júnior, ao tratar da proporcionalidade:

A premissa adquire realce em face de, na seara dos tributos, ser constitucionalmente vedado o confisco. Fixou-se, assim, um limite à imposição tributária, qual seja o de 
que esta não poderá implicar na aniquilação da atividade ou do direito de propriedade do contribuinte. Constitui uma especificação da capacidade contributiva, qual seja a de não admitir uma tributação desarrazoada. (NOBREJÚNIOR, 2001, p. 38).

O princípio da seletividade é aplicado nos impostos sobre a produção e consumo, relaciona-se com essencialidade do bem, no sentido de que, sobre mercadorias e serviços mais essenciais incidirão alíquotas menores, ao passo que sobre os mais supérfluos serão cobradas alíquotas maiores. Abel Henrique Ferreira se opõe ao entendimento de Ricardo Lôbo Torres, ao considerar a seletividade um princípio de mesmo patamar do Princípio da Capacidade Contributiva, e não um subprincípio, conforme afirma o doutrinador, estando ambos na Constituição Federal. Para Abel Henrique Ferreira, a justificativa consubstancia-se no fato de que a seletividade tem como critério a essencialidade do produto ou bem, e não a condição financeira do contribuinte, deste modo, todos pagariam o mesmo tributo indiretamente, apesar de não apresentarem a mesma quantidade de riqueza. Ainda explica o autor qual o vínculo entre tais princípios:

O princípio da seletividade visa a, através de alíquotas menores ou Base de Cálculo reduzidas, propiciar o acesso, à maioria da população, a bens de consumo final, considerados essenciais, tais como "cesta básica", em que constam produtos tais como arroz, feijão, farinhas e etc. Tal medida faz com que os preços desses produtos essenciais fiquem menores e, por conseguinte, mais acessíveis a todas as pessoas, de modo que os pobres também possam consumi-los. Tal princípio busca a igualdade do consumo mínimo e não o atendimento da capacidade contributiva dos contribuintes de dos adquirentes. Assim, quem tem maior ou menor capacidade contributiva paga, indiretamente, o mesmo valor de imposto. (FERREIRA, [200-] p. 13).

Do seu ponto de vista, portanto, a seletividade é um subprincípio da igualdade, mas não é afetada pela Capacidade Contributiva, já que a tributação leva em consideração o bem e não a capacidade. Deste entendimento, podemos concluir que a relação entre ambos é indireta, está em que o sujeito que apresenta maior Capacidade Contributiva, ou seja, maior renda, tende a consumir produtos menos essenciais, e consequentemente, será tributado com alíquotas ou base de cálculo mais altos, pagando mais tributo do que o sujeito em condição financeira inferior, pois este se limitará ao consumo de bens essenciais, cuja tributação será menor.

O princípio da progressividade, por sua vez, estabelece que o aumento da base de cálculo deve gerar o aumento da alíquota também. Há somente quatro tributos que sofrem a incidência deste princípio, são eles: ITR, IR, IPTU, cuja expressividade é expressa na própria Constituição Federal, e o ITCMD, que apesar de não ser expresso, o STF julgou possível a aplicação do princípio. A progressividade 
•• Tributação, direitos fundamentais e desenvolvimento

pode ser considerada emanação do Princípio da Capacidade Contributiva ou pode representar apenas medida de extrafiscalidade, cujo intuito é somente promover determinado comportamento e não leva em consideração a realidade financeira do contribuinte. Neste ponto, Ferreira sustenta:

Pelo estudo que realizamos, podemos concluir que o subprincípio da progressividade, para efeitos de cobrança do imposto, com obediência ao princípio da capacidade contributiva, só pode ser aplicado quando haja incremento da riqueza pessoal do contribuinte, ou seja, deve ser aplicado, em princípio, ao Imposto de Renda e ao Imposto de Transmissão "causa mortis". Nos demais casos, no máximo, poderá ser utilizado a proporcionalidade, sob pena de entrarmos na área do confisco, o que é proibido pela Carta Maior. (FERREIRA, [200-] p. 11).

Desta forma, a progressividade serviria para igualar o impacto do ônus fiscal de todos os contribuintes, pois o aumento das alíquotas do tributo deve ocorrer na medida em que for maior a riqueza do contribuinte, isto significa que quanto maior a Capacidade Contributiva, maior será o tributo pago.

\subsection{Concepções da capacidade contributiva}

Analisando a Capacidade Contributiva sob o plano jurídico- positivo, é possível observar que ela apresenta duas possíveis concepções, explicitadas a seguir.

\subsubsection{Capacidade contributiva objetiva ou absoluta}

A Capacidade Objetiva, também conhecida por Absoluta, se caracteriza diante da situação em que o legislador seleciona eventos ou fatos capazes de demonstrar riqueza. O legislador deve eleger quais serão as circunstâncias representativas de Capacidade Contributiva, e deste modo, portanto, responsáveis pelo surgimento da obrigação tributária.

Para Luís Eduardo Schoueri, a Capacidade Contributiva em sua concepção objetiva compreende o "momento que concerne à delimitação da base imponível, ou seja, as escolhas de quais elementos aferidores de economia individual formam a fonte do tributo". (SCHOUERI, 2005, apud GREGORIO, 2007, p. 47).

A Capacidade Objetiva é muito bem definida por Gregório:

Este princípio pré-jurídico é pautador pela análise objetiva da riqueza exibida pelos contribuintes e pela eleição de seu objeto, variável ao longo do tempo: seja o patrimônio, o consumo ou a renda. (GREGORIO, 2007, p. 49).

O legislador encontra-se vinculado à Capacidade Contributiva no momento de escolha das situações presuntivas de riqueza e que futuramente servirão de fato 
geradores ao tributo. Esses fatos devem ser previstos legalmente e apresentam-se de forma múltipla e variada com o passar do tempo. Ao longo da história, nota-se a eleição de diferentes objetos, tendo em vista que Capacidade Contributiva Absoluto-objetiva confere sentidos variados ao termo aptidão econômica, deixando de se referir apenas à propriedade fundiária e estendendo-se ao conjunto de bens produtivos e improdutivos relativos aos cidadãos sujeitos à tributação.

\subsubsection{Capacidade contributiva subjetiva ou relativa}

Esta segunda modalidade de Capacidade Contributiva leva em consideração a pessoa, o sujeito apto a contribuir com o Fisco na medida de suas possibilidades econômicas, por isso denominada Subjetiva. Para Paulo Gregório, são características pertinentes à Capacidade Subjetiva duas importantes funções operacionais, a primeira é que esta serve de critério de graduação do imposto, e a segunda, porque funciona como um limite à tributação, sendo que ambas devem respeitar o sujeito, levando em consideração suas aptidões econômicas. (ibidem, p. 50).

Rodrigo Alache Cordeiro aduz que "É importante salientar que a capacidade contributiva a ser buscada é capacidade subjetiva do contribuinte, ou seja, sua real aptidão para recolher tributos." (CORDEIRO, 2006, p. 101).

A Capacidade Subjetiva é, portanto, relativa por se relacionar às condições pessoais do sujeito, devido à sua verdadeira propensão ao pagamento impostos, pois o contribuinte não pode ser prejudicado em sua renda no que tange às despesas necessárias à manutenção de sua existência digna. Logo, é a sua conexão com a pessoa do contribuinte que a caracteriza.

\subsection{Capacidade contributiva e o ideal de justiça tributária}

A tributação no Brasil é disciplinada pela Constituição Federal e também por leis infraconstitucionais, deve respeitar os princípios regentes, e principalmente, promover o ideal de justiça que regula todo o ordenamento jurídico brasileiro. Por esta razão é que o Sistema Tributário Nacional deve instituir a cobrança dos tributos com vistas a realizar a justiça fiscal, ou justiça tributária.

A justiça fiscal é entendida como uma justa distribuição do ônus tributário, de modo que a carga tributária recaia sobre a totalidade de contribuintes causando impactos econômicos de mesma proporção, ainda que estes apresentem situaçôes econômico- financeiras diferentes. Sua concretização deve se pautar na busca pela equidade e isonomia, em que se tratam igualmente os iguais e desigualmente os desiguais. 
-. Tributação, direitos fundamentais e desenvolvimento

Sendo assim, a equidade na tributação significa dizer que todos sofreriam o mesmo peso na cobrança dos tributos, promovendo a justiça tributária, sendo um meio de garantir a todos uma existência digna e a promoção dos seus direitos fundamentais. Neste ponto, merece destaque o reflexo que a aplicação de uma tributação justa teria em relação à parcela mais abastada da sociedade, tendo em vista que os mais pobres são os que mais sofrem com a tributação, uma vez que há grande incidência de impostos cobrados sobre o consumo.

A justiça tributária, portanto é entendida como um limite à atuação do Estado quanto à cobrança de impostos. $\mathrm{O}$ sistema tributário nacional deve respeitar os preceitos constitucionais a fim de que se efetive a cobrança dos tributos em respeito a determinados limites. É nesta perspectiva que a Capacidade Contributiva se apresenta como um dos principais meios de consagrar a justa tributação, uma vez que ela representa a disponibilidade do contribuinte de recolher impostos de acordo suas possibilidades econômicas, respeitando o limite mínimo necessário à sua sobrevivência, e o máximo que é a vedação ao confisco. Neste sentindo, assevera Pisani:

O princípio da capacidade contributiva tem sua relevância destacada no sistema tributário por se tratar de um instrumento que legitima os meios de discriminação na tributação, além de possibilitar a graduação dos tributos. Efetivamente, é através desse preceito que se poderá estabelecer uma tributação mais equitativa, baseada nos ideais de justiça fiscal. Isso ocorre porque ao se respeitar a real capacidade contributiva daquele que sofre a exação estará se limitando o âmbito de atuação do Estado, impondo restrições à atividade tributária. (PISANI, 2010, p. 41).

Deste modo, tendo em consideração que o tributo só pode incidir quando houver Capacidade Contributiva, ou seja, situação em que respeitadas as despesas essenciais à sobrevivência, o sujeito ainda apresenta sinal de riqueza, a qual, por sua vez permitirá a tributação de forma graduada, é possível se estabelecer a tributação equilibrada, na medida em que o respeito à Capacidade Contributiva aproxima a tributação do ideal de justiça, preservando a dignidade da pessoa humana e, ao mesmo tempo, reduz as desigualdades sociais.

\subsection{Capacidade contributiva e direitos individuais}

Conforme abordado acima, a Capacidade Contributiva é um dos meios mais eficazes à garantia da justiça fiscal, por meio do qual, busca-se uma divisão isonômica dos encargos tributários. Neste contexto de adequação ao texto constitucional, bem como a todo sistema jurídico brasileiro, é necessário apontar 
outros dois principais vetores intimamente associados ao Princípio da Capacidade Contributiva.

A Capacidade Contributiva do cidadão deve ser levada em conta como meio de assegurar uma tributação justa, no entanto, para que isto se torne possível, o Princípio deve sofrer algumas limitações, como meio de assegurar o cumprimento de sua finalidade. A própria Constituição, ao estabelecer os direitos fundamentais individuais, realiza as vedações necessárias.

$\mathrm{O}$ art. 150, IV, CF/88, traz um dos limites ao poder de tributar conhecido como vedação ao efeito de confisco, em que é proibida a utilização do tributo com esse fim. $\mathrm{O}$ confisco se traduz pelo ato Estatal, seja jurídico ou administrativo, de intervir na propriedade privada a fim de satisfazer as necessidades fiscais. Para Nogueira, "A característica do confisco está exatamente em ser uma absorção coativa da propriedade, exercida pelo Poder Público ou por meio dele, 'sem indenização e sem permissão jurídica.” (NOGUEIRA, 1973, apud GREGORIO, 2007, p. 126).

Edilson Pereira Nobre Júnior muito acertadamente pontua:

Não basta a fixação de um limite mínimo, abaixo do qual, a tributação não poderia operar seus efeitos. Perniciosa, igualmente, será a instituição de tributo que afete parte substancial da renda ou propriedade. Uma tributação excessiva, que afete gravemente o patrimônio ou os rendimentos do contribuinte, poderá, sem dúvida ser capaz de afetar a subsistência daquele. Não é admissível carga tributária que, de tão elevada, desestimule o exercício de determinada atividade econômica lícita. (NOBRE JÚNIOR, 2001, p. 51).

Importante salientar que não apenas o montante do tributo pode fazer com que se torne confiscatório, mas também a matéria gravada e o motivo do gravame podem ser responsáveis por tal efeito. Logo, é vedado ao Fisco estabelecer tributos confiscatórios, que intervenham de tal modo na renda do contribuinte a ponto de lhe destruir a propriedade privada ou desestimular a liberdade de iniciativa. A Capacidade Contributiva, portanto, deve ser aplicada em consonância com os demais princípios, como o da razoabilidade, por exemplo, e respeitando o limite imposto.

Ademais, é de fundamental importância a limitação constitucional ao Princípio da Capacidade Contributiva conhecida por "mínimo existencial”, que busca delimitar o poder de tributar estatal de modo que se garanta aos cidadãos, principalmente aos menos favorecidos economicamente, o acesso a tudo que se considera 
•• Tributação, direitos fundamentais e desenvolvimento

como mínimo necessário à sobrevivência humana. Ou seja, a Capacidade Contributiva, no momento de repartir o ônus tributário, deve observar qual é a real capacidade do sujeito de contribuir com os gastos fiscais, sem que isso possa intervir na subsistência. Há um mínimo vital que deve ser respeitado e preservado, inclusive como garantia da dignidade humana.

No entendimento de Edilson Pereira Nobre Júnior, o tema é abordado do seguinte modo:

Inicialmente, há que se levar em conta a necessidade, sem dúvida intransponível, de deixar-se a salvo da tributação o mínimo vital da existência da pessoa. Trata-se de uma parcela de rendimento indisponível, em virtude de se destinar à sobrevivência do indivíduo. Esse é o patamar a ser preservado da ação fiscal. (NOBRE JÚNIOR, 2001, p. 49).

Assim sendo, não há que se falar em Capacidade Contributiva se esta não respeita as limitações impostas. Somente se torna possível a tributação equânime a partir do momento em que se asseguram os preceitos e valores constitucionais brasileiros.

\section{IMPOSTO DE RENDA PESSOA FÍSICA}

O Imposto de Renda pode ser cobrado tanto da pessoa física quanto da pessoa jurídica. É uma das principais fontes de arrecadação do Estado, portanto, um dos tributos de maior relevância atualmente, tanto pela perspectiva econômica quanto social. Neste capítulo, serão abordados alguns dos seus aspectos, observando especialmente questões pertinentes à tributação da pessoa física.

\subsection{Conceito e principais características}

O Estado possui diversos meios para manter-se economicamente, buscando equilibrar o quadro de receitas e despesas, e é dentro dessa perspectiva que existe a chamada receita derivada, oriunda das prestações patrimoniais impostas aos cidadãos. O Imposto sobre a Renda e Proventos de Qualquer Natureza, mais conhecido por Imposto de Renda (IR), integra esse conjunto de receitas derivadas, pois é um tributo exigido do cidadão mediante determinadas situações.

O Imposto de Renda é um tributo federal, portanto, compete exclusivamente à União instituí-lo, tratado no art. 153 da CF/88, inc. III. Além da Constituição Federal, há legislação extravagante que trata do IR, o Código Tributário Nacional (CTN), as Leis n. 7.713/ 88 e 9.430/96, dentre outras. 
A Constituição Federal não cria tributos, ela apenas outorga esse poder a um dos entes federativos fixando a competência tributária, sendo por este meio que a União se torna competente para instituir o Imposto sobre "rendas e proventos de qualquer natureza”. Essa expressão constitucional tem por finalidade limitar a atuação do legislador ordinário ao estabelecer o rol de situações passíveis de tributação do Imposto de Renda, isto quer dizer que a incidência do tributo só é permitida nestas hipóteses delimitadas, sob pena de se considerar inconstitucional a tributação em desacordo com a restrição legal. A fim de definir esta limitação ao Imposto de Renda é necessário conceituar tais expressōes, de acordo com Leandro Paulsen e José Eduardo Soares de Melo, "A renda é o acréscimo patrimonial produto do capital ou do trabalho. Proventos são os acréscimos patrimoniais decorrentes de uma atividade que já cessou." (PAULSEN, MELO, 2015, p. 56).

Roque Antonio Carrazza traz a seguinte definição:

(...) renda é disponibilidade de riqueza nova, havida em dois momentos distintos. (...) é o acréscimo patrimonial experimentado pelo contribuinte, ao longo de um determinado período de tempo. Ou, ainda, é o resultado positivo de uma subtração que tem, por minuendo, os rendimentos brutos auferidos pelo contribuinte entre dois marcos temporais, e, por subtraendo, o total das deduções e abatimentos, que a Constituição e as leis que com ela se afinam permitam fazer. (...) tanto a renda quantos os proventos de qualquer natureza pressupõem ações que revelem mais-valias, isto é incrementos na capacidade contributiva. Só diante de realidades econômicas novas, que se incorporam ao patrimônio da pessoa..., é que podemos juridicamente falar em renda ou proventos de qualquer natureza. (CARRAZA, 2008 apud PAULSEN, MELLO, 2015, p. 57).

Vitório Cassone aduz que renda e proventos de qualquer natureza são expressões inconfundíveis, segundo sua definição:

Renda é termo constitucional que, em teoria econômica, expressa conteúdo de riqueza, revela incremento, acréscimo, algo de conteúdo econômico passível de tributação.

Proventos de qualquer natureza é expressão constitucional que pode ser dividida em:

a) proventos em "sentido estrito" (de aposentadoria, de pensóes, de infortúnio); e

b) proventos de "qualquer natureza" (ganho de capital, ganhos ilícitos, prêmios de loteria (...)) (CASSONE, 2011, p. 255).

A partir do entendimento doutrinário é possível, portanto, compreender que a renda, cuja origem é da ciência econômica, pode ser conceituada do ponto de vista do direito tributário, em que se torna objeto do imposto, como um acréscimo de valor pecuniário no patrimônio entre dois momentos, é um acréscimo patrimonial 
•• Tributação, direitos fundamentais e desenvolvimento

obtido entre receitas e despesas, ou seja, leva em consideração os ganhos e gastos do sujeito, o que permite associá-la também ao conceito de lucro. A tributação a título de renda não pode incidir sobre o próprio capital, espécie de renda imobilizada, acumulada, ou mesmo sobre o faturamento. É necessária a delimitação no sentido de que a renda se constitui no acréscimo de riqueza, que seja produto do capital ou do trabalho durante determinado período de tempo, tornando, deste modo, legítima a tributação.

Ao passo que os proventos de qualquer natureza são os demais acréscimos patrimoniais que não derivam do capital ou do trabalho, possuem caráter residual (CARDOSO, 2008 apud PAULSEN, MELO, 2015, p. 58).

Insta ressaltar também que a jurisprudência pátria entende que sobre verbas indenizatórias não deve incidir o Imposto de Renda, inclusive é o que consta das súmulas 215 e 498 do STJ. Paulsen e Mello apontam sobre o tema:

Está bastante sedimentada, ainda, a jurisprudência no sentido de que as verbas que, por serem indenizatórias, apenas reparam uma perda, constituindo mera recomposição do patrimônio, não ensejam a incidência do imposto de renda. Isso porque não constituem riqueza nova, capaz de ensejar acréscimo patrimonial. E o legislador ordinário não pode, discricionariamente, definir como remuneratória verba que não o seja, sob pena de inconstitucionalidade. Mas, quando não apontada expressamente pelo legislador a natureza das diversas rubricas, a análise específica de cada qual, com vista a verificar se é remuneratória ou indenizatória, não é matéria constitucional, porquanto a violação à constituição, se existente, seria indireta, sendo que o STF negou repercussão geral a questóes como essa. (PAULSEN, MELO, p. 58-59).

A definição das expressões é de fundamental relevância, tendo em vista que restringe a incidência do tributo àquela parcela de rendimentos que se enquadra como renda ou como proventos de qualquer natureza, garantindo que tributação ocorra de forma justa.

\subsection{Aspectos históricos}

O IR é um imposto relativamente novo, considerado à época de sua criação um tributo irregular, visto que surgiu de maneira esporádica frente às Guerras Napoleônicas, pois era o meio que o Estado tinha de se sustentar.

O IR tem origem histórica, segundo Torres (2011, p. 379), com a criação do Estado Fiscal. As primeiras tentativas de implantação ocorreram na Inglaterra, séc. XVIII, porém sua efetivação somente ocorre no séc. XIX. Os Estados Unidos só adotam o IR mais tarde, pois foi necessária a elaboração de uma emenda constitu- 
cional que autorizasse a tributação, modificando a orientação jurisprudencial. Nos demais países, o IR passou a ser cobrado a partir do ano de 1920.

O surgimento IR está relacionado ao momento de mudança do sistema econômico, fruto da Revolução Industrial, em que a acumulação de riqueza deixa de estar atrelada a terra e passa a ligar-se ao capital industrial. Essa alteração nos meios de produção foi responsável por alterar também a base tributável, pois a tributação que inicialmente incidia sobre o patrimônio e o consumo é substituída por uma cobrança de tributos baseada na renda auferida.

Castro (2014, p. 27) aponta que no Brasil o surgimento do IR está associado ao diploma legal que impôs um tributo semelhante ao Imposto de Renda, porém que não recebia este nome. $\mathrm{O}$ art. 23 da Lei n. 317/1843, vigente durante o segundo reinado, impôs a cobrança de um imposto progressivo sobre os vencimentos recebidos pelos cofres públicos, que devido à forte reação negativa enfrentada foi logo suprimido.

Nesse sentindo, Torres aduz que "O imposto de renda e proventos de qualquer natureza adquiriu status constitucional em 1934, embora já fosse cobrado anteriormente. Sempre pertenceu à competência da União." (TORRES, 2011, p. 379).

Segundo Castro (2014, p. 28), o advento da República fez surgir também o IR, que data de dezembro de 1922, por meio do art. 31 da Lei n. 4.625. Nos anos seguintes, a cobrança do imposto vai se aperfeiçoando, até que em 1943, sua arrecadação ultrapassa pela primeira vez o imposto sobre o consumo. Neste período, o IR apresentou crescentes saltos de alíquota. No ano de 1963, o limite de sua isenção foi fixado em 24 vezes o salário mínimo mensal mais elevado vigente no país e o número de alíquotas da tabela era de dezessete, o maior da história. A partir do exercício de 1976 foi instituída a declaração com desconto simplificado, por meio do Decreto- lei n. 1.493/ 1976, que dava ao contribuinte o direito de abater da renda bruta as despesas realizadas com aluguel de sua residência, de acordo com o limite anual estabelecido. No exercício de 1991, a Secretaria da Receita Federal (SRF) instituiu o preenchimento da declaração em meio magnético, e a partir de 1997 a entrega da declaração de ajuste anual passa a ser pela Internet.

Com a CF/88, a legislação do IR torna-se mais concisa, apresenta melhores estruturas de apuração quanto ao rendimento tributável e às deduções, fazendo do IR o principal imposto atual, com a maior fonte de renda para o país. 
•• Tributação, direitos fundamentais e desenvolvimento

\subsection{Imposto de renda na Constituição Federal e no CTN}

A CF/88 trata da competência tributária do IR em seu art. 153, isto quer dizer que a Constituição dá a um dos entes federativo, neste caso a União, o poder de criar, instituir ou majorar o tributo. A competência tributária não deve ser confundida com a competência para legislar o direito tributário.

Logo, a CF não cria o IR, ela outorga este poder de criar, instituir ou majorá-lo à União, do seguinte modo:

Art. 153. Compete à União instituir impostos sobre:

III. renda e proventos de qualquer natureza;

$\$ 2^{\circ}$. O imposto previsto no inciso III:

I - será informado pelos critérios da generalidade, da universalidade e da progressividade, na forma da lei;

II - (Revogado pela Emenda Constitucional n. 20, de 15-12- 1998.) (CF/88)

É possível observar que a CF não estabelece profunda definição do IR, apenas aborda de modo sucinto sua competência. Não há, pelo texto constitucional, a definição de renda ou proventos de qualquer natureza, pois conforme dito anteriormente, cabe ao legislador ordinário fazê-lo, a fim de estabelecer um limite ao objeto tributável pelo IR. Ricardo Lobo Torres afirma que:

A renda e proveitos são conceitos constitucionais abertos, que devem ser trabalhados pela doutrina e pela legislação. A CF não opta por qualquer das teorias elaboradas sobre a noção de renda nem define o fato gerador do tributo. O legislador tem, portanto, liberdade para a concretização normativa, respeitados os limites do sentido possível do conceito de renda, acrescido da noção residual de proventos, como acréscimo de patrimônio em determinado lapso de tempo. (TORRES, 2011, p. 379).

Torres também afirma que cabe à legislação ordinária a distinção entre Imposto de Renda das Pessoas Físicas e das Pessoas Jurídicas, pois desta forma é possível realizar os ajustamentos quanto à incidência de ambos sem que seja necessária a reforma da CF ou da lei complementar. (ibidem, p. 380).

$\mathrm{O} \$ 2^{\circ}$ aborda os princípios informadores da tributação sobre o IR, tratados a seguir, estabelecendo uma relação de subordinação entre a cobrança do tributo e valores presentes no ordenamento jurídico, de modo que o respeito a tais critérios é uma adequação necessária à legislação tributária.

Ademais, a CF cita a súmula 125 do STJ, que estabelece a não incidência do Imposto de Renda sobre o pagamento de férias não gozadas por necessidade de serviço. 
No que tange à matéria infraconstitucional, merece destaque a abordagem que o Código Tributário Nacional (CTN) faz sobre o IR:

Art. 43. O imposto, de competência da União, sobre a renda e proventos de qualquer natureza tem como fato gerador a aquisição da disponibilidade econômica ou jurídica;

I - De renda, assim entendido o produto de capital, do trabalho ou da combinação de ambos;

II - De proventos de qualquer natureza, assim entendidos os acréscimos patrimoniais não compreendidos no inciso anterior.

$\$ 1^{\circ}$ A incidência do imposto independe da denominação da receita ou do rendimento, da localização, condição jurídica ou nacionalidade da fonte, da origem e da forma de percepção.

$\$ 2^{\circ} \mathrm{Na}$ hipótese de receita ou de rendimentos oriundos do exterior, a lei estabelecerá as condiçôes e o momento em que se dará sua disponibilidade, para fins de incidência do imposto referido neste artigo.

Art. 44. A base de cálculo do imposto o montante, real, arbitrado ou presumido, da renda ou dos proventos tributáveis.

Art. 45. Contribuinte do imposto é o titular da disponibilidade a que se refere o artigo 43, sem prejuízo de atribuir a lei essa condição ao possuidor, a qualquer título, dos bens produtores de renda ou dos proventos tributáveis.

Parágrafo único. A lei pode atribuir à fonte pagadora da renda ou dos proventos tributáveis a condição de responsável pelo imposto cuja retenção e recolhimento lhe caibam. (CTN)

O tributo é tratado de forma pormenorizada, por meio da qual se estabelece o conceito de renda e de proventos de qualquer natureza. O CTN complementa a legislação ao definir que a incidência do Imposto não depende de fatores como denominação ou origem da renda, por exemplo. Além disso, determina como deve ser apurada a base de cálculo do Imposto, ou seja, qual o montante realmente foi tido como rendimento e define o sujeito passivo da relação jurídica, isto é, quem mais além do contribuinte poderá figurar no polo passivo da relação e sofrer a cobrança do IR.

\subsection{Princípios orientadores}

A CF prevê expressamente que o IR deve atender aos critérios da generalidade, universalidade e progressividade, o que implica dizer que a tributação do Imposto deve ter por base tais princípios constitucionais, pois funcionam como normas fundamentais e devem ter respeitados seus valores. 
•• Tributação, direitos fundamentais e desenvolvimento

Além destes, a CF prevê também, art. 145, que os impostos deverão ter caráter pessoal e sua graduação deverá observar a capacidade econômica do contribuinte. Tendo em vista o papel fundamental dos princípios no ordenamento jurídico, devido à função de orientar a criação de normas em consonância com seu sentido axiológico, é imprescindível que a legislação e a cobrança do IR obedeçam tais preceitos. Quanto à relevância dos princípios, Celso Bandeira de Mello pontua:

Princípio é, por definição, mandamento nuclear de um sistema, verdadeiro alicerce dele, disposição fundamental que se irradia sobre diferentes normas compondo- lhes o espírito e servindo de critério para a exata compreensão e inteligência, exatamente por definir a lógica e racionalidade do sistema normativo, no que lhe confere a tônica e lhe dá sentido harmônico. É o conhecimento dos princípios que preside a intelecção das diferentes partes componentes do todo unitário que há por nome sistema jurídico positivo. (MELLO, 2010 apud HORN, 2013, p. 16).

$\mathrm{O}$ art. $145, \$ 1^{\circ}$, da $\mathrm{CF}$, conforme já analisado anteriormente, ao dizer que os impostos deverão atender à capacidade econômica do contribuinte, na verdade, está se referindo ao Princípio da Capacidade Contributiva, segundo o qual a contribuição para com o Fisco deve ser graduada de acordo com a capacidade que cada sujeito tem de contribuir, ou seja, a cobrança do imposto deve causar impactos de iguais proporções à totalidade dos sujeitos passivos, independentemente da sua condição financeira. Deste modo, é necessário observar a capacidade econômica do sujeito passivo para que seja possível aferir qual será sua Capacidade Contributiva. Torres afirma que:

A capacidade contributiva se subordina à ideia de justiça distributiva. Manda que cada qual pague o imposto de acordo com a sua riqueza, atribuindo conteúdo ao vetusto critério de que a justiça consiste em dar a cada um o que é seu (suum cuique tribuere) e que se tornou uma das "regras de ouro" para se obter a verdadeira justiça distributiva. Existe igualdade no tributar cada qual de acordo com a sua capacidade contributiva, mas essa tributação produz resultados desiguais por se desigualarem as capacidades contributivas individuais (TORRES, 2011, p. 93).

Torres assevera, portanto, que a Capacidade Contributiva está associada à ideia de justiça distributiva. Além disso, aponta que os princípios insculpidos no art. 153, I, da CF, que orientam a tributação sobre a renda, quais sejam, generalidade, universalidade e progressividade são subprincípios da Capacidade Contributiva, ou seja, estão diretamente vinculados a este, tornando ainda maior sua concretização. (ibidem, p. 87).

Também inserto ao art. $145, \$ 1^{\circ}$, da CF está o princípio da personalização. Ao se referir à necessidade que o imposto tem de atender ao caráter pessoal, o legislador 
constituinte institui que a cobrança dos impostos deve levar em consideração as condiçõoes pessoais do sujeito passivo da obrigação tributária, analisando as características individuais dos contribuintes. (HORN, 2013, p. 17).

Para Aliomar Baleeiro:

(os impostos pessoais) são regulados por critérios que contemplam a individualidade do contribuinte. As condições personalíssimas deste são elementos que se integram à formação do fato gerador e determinam as variaçôes para mais, ou menos, na fixação do quantum a ser reclamado pelo Fisco. (BALEEIRO, 1977 apud HORN, 2013, p. 18).

Portanto, o IR deverá estar em harmonia com o art. $145, \mathbb{1}$, da CF que combina os dois princípios acima detalhados, e que por consequência, se vinculam aos demais princípios, ou subprincípios, abarcados pelo art. 153, inc. I, da CF.

O princípio da generalidade tem por escopo garantir a isonomia tributária, de modo que o IR seja exigido de todos que tenham praticado seu fato gerador. Isto significa dizer que a cobrança do IR deve alcançar a generalidade de pessoas que auferirem renda. A incidência do tributo deve ocorrer sem discriminações ou exceçôes de natureza pessoal.

Para Roque Antonio Carrazza:

Por generalidade entendemos que o imposto há de alcançar todas as pessoas que realizam seu fato imponível. E isto independentemente de raça, sexo, convicções, políticas, credo religioso, cargos ocupados etc. Noutros falares, este critério veda discriminações e privilégios entre os contribuintes. (CARRAZZA apud GUTIERREZ, 2009, p. 82).

Gutierrez aponta que:

A Constituição brasileira também veda expressamente qualquer privilégio em matéria fiscal, com especial relevo no que toca ao imposto de renda. De fato, determina o art. 153, $\$ 2^{\circ}$, I, da Carta Magna que o imposto de renda será informado pelo princípio da generalidade. A introdução do referido preceito em nossa Constituição Federal visou a que fossem abolidos quaisquer privilégios em matéria de imposto de renda. (GUTIERREZ, 2009, p. 78).

Enquanto o princípio da generalidade se refere à totalidade de sujeitos passivos da obrigação tributária do IR, o princípio da universalidade, por sua vez, determina que a tributação deva incidir igualmente sobre a totalidade de rendas e proventos auferidos pelo contribuinte, sendo proibida distinção quanto à sua origem ou fonte. Qualquer que seja o acréscimo patrimonial auferido pelo contribuinte, o IR deve necessariamente incidir. (GUTIERREZ, 2009, p. 100). 
•• Tributação, direitos fundamentais e desenvolvimento

Logo, é possível observar que pelo princípio da universalidade, o IR abrange todo o "universo" de renda, isto é, abrange a totalidade de renda auferida pelo sujeito, pessoa física ou jurídica, independentemente desta renda ser derivada de meios lícitos ou não, por exemplo. Todo e qualquer tipo de renda será tratada da mesma forma pelo tributo.

A esse respeito, Hugo de Brito Machado muito bem pontua dizendo que "ao objeto da tributação, devendo o imposto então recair sobre todos os rendimentos, independentemente da denominação que tiverem, da sua origem, da localização ou condição jurídica da respectiva fonte" (MACHADO apud GUTIERREZ, 2009, p. 101).

Por fim, resta analisar o princípio da progressividade, que sob a ótica de Vitorio Cassone é abordado da seguinte forma: "Tem-se, de regra, que progressivo é o imposto que, tendo duas ou mais alíquotas, o montante do imposto vai aumentando desproporcionalmente em função do valor tributável." (CASSONE, 2011, p. 256).

Sérgio Vasconcellos Horn aduz que:

A justificativa jurídica do princípio da progressividade da tributação tem no juízo de equidade seu fundamento último. Dentre as proposições articuladas por Aristóteles em sua investigação da natureza e das relações recíprocas entre as virtudes morais, vertidas no tratado ético-moral intitulado Ética a Nicômaco, aquelas resultantes do estudo dedicado ao problema do justo, de que se ocupa o livro V, se prestam a amparar a superioridade do princípio da progressividade na formulação das leis tributárias. (HORN, 2013, p. 24).

\section{Para Francesco Forte:}

A progressividade do sistema fiscal em relação à renda foi defendida com vários argumentos: o mais notável e o mais debatido é aquele do sacrifício, que repousa sobre o princípio da utilidade decrescente da renda. Para proporcionar um sacrifício igual a dois contribuintes, um rico e um pobre, sustentou-se que (a tese é de J.S. MILL) é preciso cobrar muito mais do primeiro que do segundo, porque uma lira tirada do rico é, para ele, uma perda muito menor que uma lira tirada do pobre. Além do mais, em termos de 'sacrifício igual', o princípio da repartição em base ao sacrifício foi formulado em termos de sacrifício mínimo coletivo: para causar o menor sacrifício total ao grupo, alegou-se (a primeira formulação rigorosa é de EDGEWORTH) que se deve tomar o dinheiro de preferência do rico, porque para ele esse dinheiro tem menor utilidade marginal, que do pobre. Uma outra elaboração (sobretudo de COHEN STUART e, na Itália, a LIONELLO ROSSI) é em termos de sacrifício proporcional. É dito que, para que a tributação progressiva seja justificada, sob a regra do sacrifício igual ou proporcional, o decréscimo da utilidade deve ser acentuado (a demonstração é de EDGEWORTH e é claramente desenvolvida, entre outros, por PIGOU e por D' ALBERGO). (...) (FORTE, 1982 apud CASSONE, 2011, p. 259). 
Portanto, conclui-se que a progressividade diz respeito ao aumento da alíquota em razão do montante tributável. Quando uma alíquota é progressiva, ela aumenta à medida que se aumenta a base de cálculo. Significa dizer que quanto maior for renda, mais progressiva será a alíquota, e o valor pago a título de imposto será mais que proporcional ao valor da renda auferida, visto que com o aumento desta, aumentar-se-á também a alíquota incidente. A justificativa para este modelo de tributação é a busca pela equidade, conforme visto, pois leva em consideração que a cobrança sob valores iguais de alíquotas causariam sacrifícios de proporçôes muito maiores à camada mais pobre da população.

\subsection{Aspectos normativos: obrigação tributária, fato gerador da obrigação tributária, sujeito ativo e passivo, base de cálculo, alíquotas e isenção}

$\mathrm{O}$ art. 43 do CTN, que disciplina o IR, determina que seu fato gerador é a aquisição da disponibilidade econômica ou jurídica da renda ou dos proventos de qualquer natureza. A definição do fato gerador, por sua vez, é apontada pelo art. 14 do CTN da seguinte forma: "Fato gerador da obrigação principal é a situação definida em lei como necessária e suficiente à sua ocorrência”. Torres explica que "Fato gerador é a circunstância da vida- representada por um fato, ato ou situação jurídica- que, definida em lei, dá nascimento à obrigação tributária.” (TORRES, 2011, p. 243).

Partindo desse entendimento, cabe analisar a situação jurídica que dará ensejo ao surgimento da obrigação tributária do IR, ou seja, a aquisição da disponibilidade econômica ou jurídica.

O plenário do XI Simpósio Nacional de Direito Tributário assim o definiu:

Aquisição de disponibilidade jurídica de renda e proventos de qualquer natureza é a obtenção de direitos de crédito, não sujeitos à condição suspensiva.

Aquisição da disponibilidade econômica de renda e proventos de qualquer natureza é a obtenção da faculdade de usar, gozar ou dispor de dinheiro ou de coisa nele conversível, entrados para o patrimônio do adquirente por ato ou fato jurídico.

O fato gerador do IR sobre o lucro das PJ aperfeiçoa-se no momento em que se completa o período de apuração do lucro, como determinado pela lei aplicável.

O fato gerador do IR sobre a renda líquida da PF aperfeiçoa-se no momento em que se completa o período de apuração das receitas e deduções cuja soma algébrica constitui a renda líquida. (XI SIMPÓSIO apud CASSONE, 2011, p. 266). 
-• Tributação, direitos fundamentais e desenvolvimento

Gutierrez explica que:

A doutrina denominou a primeira situação disponibilidade jurídica, ou seja, quando o contribuinte possui título jurídico para o recebimento da renda, e a segunda, disponibilidade econômica, ou seja, quando a renda já está nas mãos do seu titular. A disponibilidade jurídica ocorre na aquisição do direito à renda, sem que tenha havido ainda a sua percepção em dinheiro ou bens suscetíveis de avaliação em dinheiro, percepção esta que representa a disponibilidade econômica. (GUTIERREZ, 2009, p. 38).

Logo, é pertinente a compreensão do que seria a disponibilidade jurídica ou econômica para a consideração do Imposto de Renda Pessoa Física (IRPF), que representa o critério material deste imposto. Com base nos ensinamentos doutrinários e na própria lei, pode-se considerar que a disponibilidade representa a aquisição de um direito por parte do contribuinte, um acréscimo de seu patrimônio, seja com o ingresso de receita, em que há a percepção do dinheiro ou bem suscetível de avaliação em dinheiro, caso em que caracteriza a disponibilidade econômica; ou por meio de um direito adquirido quanto à determinada receita, que apesar de ainda não ter sido percebida, seu simples registro já representa um acréscimo do patrimônio e, portanto, passível de tributação.

Com a prática do fato gerador, cujo critério temporal é o momento de aquisição da disponibilidade ou da obtenção da renda e proventos de qualquer natureza, há o surgimento da obrigação tributária, que por sua vez, gera ao sujeito passivo o dever de pagar o tributo. A relação tributária estabelecida pela obrigação do IR determina que o seu sujeito ativo, ou seja, a pessoa jurídica de direito público titular da competência para exigir o seu cumprimento (conforme definição do art. 119 do CTN) será a União, art. 153, III, CF. Ao passo que o sujeito passivo, pessoa obrigada à prestação, ou ainda o contribuinte do imposto, será "o titular da disponibilidade a que se refere o art. 43, sem prejuízo de atribuir a lei essa condição ao possuidor, a qualquer título, dos bens produtores de renda ou proventos de qualquer natureza” (art. 45, CTN). É possível também a atribuição, por lei, à fonte pagadora da renda ou dos proventos tributáveis a condição de responsável pelo Imposto, cuja retenção e recolhimento lhe caibam, isto é, ainda que o responsável não possua relação direta com a situação do fato gerador e, portanto, não se constitua como contribuinte, também será obrigado a pagar o tributo, tornando-se também sujeito passivo da relação.

No que tange ao critério quantificativo, o IR apresenta como base de cálculo "o montante real, arbitrado ou presumido, da renda ou de proventos de qualquer 
natureza”, art. 44 do CTN. Já as alíquotas do IR, em especial do IRPF, são valores percentuais progressivos, em que se estabelece uma tributação por faixas de renda, garantindo um valor de isenção, a partir do qual há incidência do tributo sobre a renda de forma progressiva, pois o valor percentual aumenta em razão do montante da base de cálculo, respeitando o art. 153, III, $\$ 2^{\circ}$ da CF.

Sobre a imunidade no IRPF, Ricardo Lobo Torres brevemente diz que:

A CF declarava (art. 153, $\$ 2^{\circ}$, II) a imunidade dos rendimentos provenientes de aposentadoria e pensão, pagos pela previdência social a pessoa com idade superior a 65 anos, cuja renda total fosse constituída, exclusivamente, de rendimentos do trabalho. O dispositivo, que era cláusula pétrea foi revogado inconstitucionalmente pela EC 20/98; mas a imunidade sobrevive implicitamente ao lado de outras que se afirmam em homenagem ao mínimo existencial. (TORRES, 2011, p. 380).

Com as considerações apontadas, que permitem melhor compreensão sobre o Imposto, é de grande relevância a análise do instituto da isenção para os tributos, em especial para o IRPF, conforme segue abaixo.

\subsection{Isenção do IR}

A isenção tributária tem por finalidade uma atuação extrafiscal, em que a instituição do tributo se dá em consonância com princípios constitucionais, como o da justiça fiscal, da igualdade e da isonomia, e busca, dessa forma, garantir uma tributação que vise não apenas a arrecadação de receitas, mas também que promova o desenvolvimento social e que assegure os direitos individuais, como o mínimo existencial.

Ao se referir à atuação Estatal no sentido de proporcionar um beneficiamento econômico e social, Gadelha aponta que:

Com efeito, a atividade financeira do Estado passou a se voltar não ao mero incremento dos cofres públicos para posterior dispêndio custeador das necessidades públicas. A tributação não deve considerar apenas a finalidade arrecadatória; não deve perseguir o desenvolvimento social e econômico como fim da atividade impositiva. (GADELHA, 2006, p. 83).

Sob este ponto de vista, portanto, a isenção dos tributos é entendida como uma política de estímulo a políticas sociais, cujo objetivo principal é o desenvolvimento social e redução das desigualdades, pois a partir de uma aplicação pautada na razoabilidade, o Estado protege a camada mais desfavorecida da sociedade.

Ruy Barbosa traz o seguinte conceito à isenção: 
•• Tributação, direitos fundamentais e desenvolvimento

A isenção é concedida por lei tendo em vista não o interesse individual, mas o interesse público. Assim, a isenção outorgada às pessoas como aos bens é concedida em função da situação em que essas pessoas ou esses bens se encontram em relação ao interesse público, exigindo ou justificando um tratamento isencional.

Isto quer dizer que é a própria lei que descreve objetivamente essas situações e considera que essas pessoas enquadradas dentro delas estão numa situação diferente das demais e por isso devem ter também um tratamento diferente, em atenção ao princípio da isonomia ou igualdade. (NOGUEIRA, 1999 apud CASSONE, 2011, p. 127).

Ricardo Lobo Torres considera a isenção como um privilégio jurídico (privilégio não odioso), pois a lei concede uma exceção à regra geral e, ao mesmo tempo, a interpreta também como uma autolimitação do poder fiscal (TORRES, 2011, p. 308).

Neste mesmo sentindo, Gadelha diz que "Assim, singelamente, a isenção tributária, como uma limitação legal do âmbito de validade da norma jurídica tributária, é entendida como um atributo decorrente da própria competência de tributar." (GADELHA, 2006, p. 95).

Desse modo, sem adentrar no mérito da natureza jurídica do instituto da isenção, visto que o próprio CTN revela-se neutro neste ponto, sua compreensão como uma autolimitação fundamenta-se no fato de que o próprio ente titular da competência tributária é quem estabelecerá limites à sua atuação fiscal, concedendo uma espécie de favor fiscal ao dispensar o pagamento do tributo.

De grande relevância para o entendimento da isenção dentro do ordenamento jurídico brasileiro, especialmente em relação ao IRPF, Ricardo Lobo Torres assevera que há grande subordinação dela em relação aos princípios constitucionais, como o da justiça, o que permite concluir que a concessão da isenção não deve ser entendida como "privilégio- odioso", tendo em vista que o tratamento diferenciado se fundamenta na razoabilidade quanto às desigualdades e na Capacidade Contributiva do sujeito, conforme segue:

Um dos mais importantes princípios constitucionais da isenção é o da capacidade contributiva. O benefício deve ser concedido a quem não tenha capacidade econômica para suportar o ônus do tributo. Aplica-se sobretudo às isenções genéricas e gratuitas, que procuram amparar as camadas da população de menor poder aquisitivo. Se os beneficiários, entretanto, possuírem forte capacidade contributiva, a isenção perde o seu fundamento jurídico e se aproxima do privilégio odioso proibido pelo art. 150, II, da CF 88, a não ser que encontre justificativa no princípio do desenvolvimento econômico. (TORRES, 2011, p. 311). 
$\mathrm{O}$ art. $150, \$ 6^{\circ}$ da $\mathrm{CF} / 88$ determina que a isenção deve ser concedida mediante lei específica, como ocorre com a Lei n. 7.713/88, que traz o rol de situações de isenção ao IRPF e a Lei n. 13. 149/ 15, a qual dispõe sobre o seu atual limite de isenção: determina as faixas de tributação com o valor da alíquota progressiva correspondente e dispõe que a partir do mês de abril do ano-calendário de 2015 (art. 1, IX), sobre a base de cálculo cujo valor não ultrapasse R \$ 1.903,98 não haverá cobrança do IRPF, limite correspondente à atual isenção.

Com base no entendimento doutrinário sobre o tema, conclui-se, logo, que as situações passíveis de isenção do IR, bem como o limite de renda sobre o qual o imposto não é cobrado, são normas orientadas pela consecução de um bem comum: o desenvolvimento social. Em decorrência desse fim e em consonância com os princípios regentes no ordenamento jurídico, a isenção deve obrigatoriamente pautar-se no ideal de justiça, levando em consideração a Capacidade Contributiva do sujeito e garantindo tratamento isonômico. Para tanto, cabe analisar se o instituto mostra-se apto a garantir os fins que lhe foram propostos, conforme segue adiante.

\section{ANÁlISE CRÍTICA SOBRE A RELAÇÃO DA ISENÇÃO E A CAPACIDADE CONTRIBUTIVA ATUALMENTE}

A isenção do IR deve-se pautar no Princípio da Capacidade Contributiva como meio de garantir o ideal de justiça tributária. Cabível, portanto, uma análise acerca do atual limite de isenção do tributo com intuito verificar a relação entre ambos, e com isso propor uma justa atualização e correção do valor visando garantir os direitos abarcados pela Constituição Brasileira.

\subsection{Reflexos do princípio da capacidade contributiva sobre o limite de isenção do imposto de renda}

Com a análise do Princípio da Capacidade Contributiva e a compreensão do estreito relacionamento deste com demais princípios constitucionais, é possível observar a influência direta e orientadora que tal princípio deve manter sobre o limite de isenção do IR, senão vejamos.

Um Estado democrático de Direito se pauta por princípios como o da igualdade e da dignidade humana, cujo objetivo principal é assegurar o desenvolvimento da sociedade de forma genérica, isto é, garantir a todos os cidadãos as mesmas oportunidades, os mesmos direitos e os mesmos deveres. Os princípios constitucionais 
-• Tributação, direitos fundamentais e desenvolvimento

brasileiros têm a finalidade de garantir os direitos fundamentais e uma existência digna a toda sociedade, sem qualquer tipo de distinção ou discriminação.

Neste ponto merecem destaque os princípios atinentes à ordem fiscal, como um dos meios de assegurar a igualdade perante os contribuintes. O Sistema Tributário tem em vista o ideal de justiça fiscal, este por sua vez, concretiza-se através dos princípios orientadores.

Conforme visto, o princípio da igualdade estabelece que aos contribuintes em situação equivalente é necessária a instituição de igual tratamento. Insculpido no art. 150, II, da CF/ 88, o princípio da igualdade veda o comportamento dos entes federativos que tem por fim desigualar as pessoas, bens, atividades econômicas, situações jurídicas ou de fato que estejam em patamar de equivalência. Com isso, busca-se proibir os privilégios odiosos e a discriminação fiscal.

O princípio da igualdade, também conhecido como princípio da isonomia, determina tratamento igual aos iguais e desigual aos desiguais. Um dos princípios de maior relevância ao ordenamento jurídico, pois se atenta para a situação de fato do cidadão, neste caso, para a realidade financeira do contribuinte, com o fim de atingir uma igualdade material, e não apenas formal, visto que se o Estado não observa as peculiaridades entre os diferentes níveis econômicos e não leva em consideração as circunstâncias sociais que prevalecem sobre os diferentes grupos da sociedade, acaba por imprimir uma atuação desarrazoada, pois a lei perde seu fundamento de ser e torna-se injusta.

Neste ponto, Feitosa, Frattari e Lima (2015, p. 300) explicam que "Na presença de desigualdades sociais deve-se buscar a igualdade real para pôr em prática a nivelação das posições desiguais, senão em vez de gerar o direito, gerar igualdades, gera mais desigualdades."

O desdobramento dessa ideia de igualdade e isonomia acarretam na realização da igualdade tributária, explicada da seguinte forma "O que o constituinte originário prescreve é a observância do princípio da igualdade tributária ao proibir que o legislador tributário institua tratamento desigual entre contribuintes em situação equivalente." (ibidem, p. 302).

A igualdade tributária, portanto, deve analisar a real situação do contribuinte ao instituir a tributação, e isso ocorre por meio da aferição da Capacidade Contributiva do sujeito passivo, pois para Amaro "Serão tratados com igualdade aqueles com igual capacidade contributiva, e com desigualdade os que revelem riquezas 
diferentes e, portanto, diferentes capacidades de contribuir" (AMARO, 2006, apud FEITOSA, FRATTARI, LIMA).

Se a Capacidade Contributiva é então o meio de realização da igualdade no campo tributário, é necessário que o Fisco exerça tributação apenas quando houver signos de riqueza, pois caso o sujeito passivo não demonstre a capacidade de contribuir com os gastos públicos, torna-se claro que a tributação está excedendo os limites constitucionais. A cobrança dos tributos não pode interferir na situação econômica do sujeito de modo a prejudicar-lhe o acesso ao que se considera básico à manutenção da vida, ou seja, a tributação deve respeitar os limites instituídos pela CF de garantia ao mínimo existencial e vedação do confisco.

No momento em que a tributação não preserva este ideal do que seria o mínimo necessário, ou ainda, venha a interferir nos recursos destinados, por exemplo, à execução de atividade profissional do sujeito, comprometendo o seu orçamento, não há que se falar em demonstração de riqueza, menos ainda em capacidade de contribuir, pois a retirada de qualquer parcela de rendimentos representaria-lhe um empobrecimento.

Deste modo, entende-se que o IR, como um dos princípios que mais realiza o Princípio da Capacidade Contributiva, deve obrigatoriamente respeitar tais preceitos com o fim de garantir uma justa tributação, sem onerar demasiadamente a parcela mais frágil da sociedade. A cobrança do Imposto deve ser equilibrada no sentido de não causar impactos de diferentes proporçóes às pessoas de variados níveis socioeconômicos, e com vistas a concretizar tal finalidade é que se entende necessário o estabelecimento de um limite de isenção.

Por meio de um justo valor isentivo, O Estado alcança seu objetivo principal, que é a arrecadação aos cofres públicos, e ao mesmo tempo, respeita os mandamentos constitucionais, pois desobriga da contribuição uma parcela da sociedade que faz uso da integralidade da renda auferida para atender às necessidades básicas de manutenção da vida. Daí a importância de se considerar o Princípio da Capacidade Contributiva ao instituir um limite ao valor de isenção do IR.

\subsection{Tabela do imposto de renda: comparação entre o valor atual de isenção e os demais}

É de fundamental importância uma análise sucinta e objetiva acerca dos últimos valores instituídos à isenção do IR. Através deste exame, é pertinente a discussão 
•• Tributação, direitos fundamentais e desenvolvimento

quanto à correição do atual limite, ou seja, o questionamento se a faixa de isenção vigente hoje corresponde a um limite considerado justo e se atende aos princípios orientadores do direito tributário.

No período correspondente aos anos de 1993 a 2001 os valores anuais de isenção do imposto de renda eram os seguintes, conforme dados da Receita Federal:

\section{Histórico da Tabela Progressiva do IRPF}

\begin{tabular}{|c|c|c|c|c|c|c|c|c|c|c|c|c|}
\hline \multirow[t]{2}{*}{ Exercicio } & \multicolumn{2}{|c|}{$\begin{array}{c}1993 \text { e } 1994 \\
\text { Reais }^{*}\end{array}$} & \multicolumn{2}{|c|}{$\begin{array}{l}1995 \\
\text { Reais* }\end{array}$} & \multicolumn{2}{|c|}{$\begin{array}{l}1996 \\
\text { Reais }\end{array}$} & \multicolumn{2}{|c|}{$\begin{array}{l}1997 \\
\text { Reais }\end{array}$} & \multicolumn{2}{|l|}{$\begin{array}{l}1998 \\
\text { Reais }\end{array}$} & \multicolumn{2}{|c|}{$\begin{array}{c}1999 \text { a } 2001 \\
\text { Reais }\end{array}$} \\
\hline & BC & Aliq & BC & Aliq & BC & Aliq & BC & Aliq & BC & Aliq & BC & Alíq \\
\hline \multirow{4}{*}{ 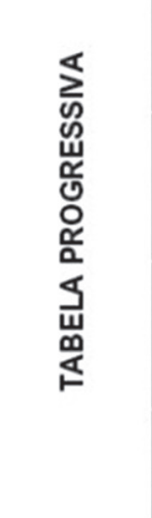 } & $\begin{array}{c}\text { Até } \\
9.543,0\end{array}$ & & $\begin{array}{c}\text { Até } \\
9.543 .0\end{array}$ & & $\begin{array}{c}\text { Até } \\
8.803,4\end{array}$ & & $\begin{array}{c}\text { Até } \\
10.800 .00\end{array}$ & & $\begin{array}{c}\text { Até } \\
10.800,00\end{array}$ & & $\begin{array}{c}\text { Até } \\
10.800,00\end{array}$ & \\
\hline & $\begin{array}{c}\text { Acima de } \\
9.543,0 \\
\text { até } \\
18.609,0\end{array}$ & 15 & $\begin{array}{c}\text { Acima de } \\
9.543,0 \\
\text { até } \\
18.609,0\end{array}$ & 15 & $\begin{array}{c}\text { Acima de } \\
8.803,4 \\
\text { até } \\
17.166 .3\end{array}$ & 15 & $\begin{array}{c}\text { Acima de } \\
10.800,0 \\
\text { até } \\
21.600,0\end{array}$ & 15 & $\begin{array}{c}\text { Acima de } \\
10.800,0 \\
\text { até } \\
21.600,0\end{array}$ & 15 & $\begin{array}{c}\text { Acima de } \\
10.800 .0 \\
\text { até } \\
21.600,0\end{array}$ & 15 \\
\hline & $\begin{array}{l}\text { Acima de } \\
18.609,0\end{array}$ & 25 & $\begin{array}{c}\text { Acima de } \\
18.609,00 \\
\text { até } \\
171.771,0\end{array}$ & 26,6 & $\begin{array}{c}\text { Acima de } \\
17.166,30 \\
\text { até } \\
158.457,4\end{array}$ & 26,6 & $\begin{array}{l}\text { Acima de } \\
21.600,0\end{array}$ & 25 & $\begin{array}{l}\text { Acima de } \\
21.600,0\end{array}$ & 25 & $\begin{array}{l}\text { Acima de } \\
21.600,0\end{array}$ & 27,5 \\
\hline & & & $\begin{array}{l}\text { Acima de } \\
171.771,0\end{array}$ & 35 & $\begin{array}{l}\text { Acima de } \\
158.457,4\end{array}$ & 35 & & & & & & \\
\hline
\end{tabular}

Valores em Reais convertidos pela UFIR média de 1995 (0,79524)

Elaboraçäo: COSIT/SRF

Fonte: Receita Federal ${ }^{1}$.

Nos anos seguintes:

\begin{tabular}{cc}
\hline Ano & Base de cálculo anual \\
\hline 2002 & Até R\$ 10.800,00 \\
\hline $2003 / 04 / 05$ & Até R\$ 12.696,00 \\
\hline 2006 & Até R\$ 13.968,00 \\
\hline 2007 & Até R\$ 14.992,32 \\
\hline 2008 & Até R\$ 15.764,28 \\
\hline
\end{tabular}

Disponível em: <http://idg.receita.fazenda.gov.br/acesso-rapido/tributos/irpf-imposto-de-rendapessoa-fisica $>$. 


\begin{tabular}{cc}
\hline 2009 & Até R\$ 16.473,72 \\
\hline 2010 & Até R\$ 17.215,08 \\
\hline 2011 & Até R\$ 17.989, 80 \\
\hline 2012 & - \\
\hline 2013 & Até R\$ 19.645,32 \\
\hline 2014 & Até R\$ 20.529,36 \\
\hline 2015 & Até R\$ 21.453,24 \\
\hline 2016 & Até R\$ 22.499,13 \\
\hline 2017 & Até R\$ 22.847,76
\end{tabular}

Com base nos dados informativos acima é possível fazer uma comparação dos valores de isenção ao longo dos anos, constatando-se que: no ano de 1994 o valor anual de isenção era limitado a $\mathrm{R} \$ 9.543,00$, equivalente a $\mathrm{R} \$ 795,25$ mensais, sendo que neste mesmo período o salário mínimo vigente era aproximadamente de $\mathrm{R}$ \$ 70,00, conforme MP n. 598/94, o que permite concluir que a isenção mensal correspondia a mais de 11 vezes o valor do salário mínimo.

Em 1996 essa correspondência caiu para 6,5 salários mínimos, voltando a subir em 1997 para 7,5. Ao passo que o atual valor de isenção, qual seja, $\mathrm{R}$ 22.499,13, ou R \$ 1.903,98 mensais, representa pouco mais de 2 vezes o valor do salário mínimo vigente.

A obtenção de resultados com valores tão díspares fomenta o debate acerca da atual isenção, pois ao apresentar um limite desatualizado, a tributação do IR pode acarretar em injustiça tributária.

\subsection{Defasagem do valor: relação com índices inflacionários e poder de compra}

Outro aspecto de grande relevância tocante ao IR e que vem sendo alvo de discussões atualmente diz respeito à desatualização apresentada pela suas faixas de valores que resultam em uma grande defasagem e afeta principalmente a camada mais inferior da sociedade.

O governo federal deve obrigatoriamente realizar a correção da tabela do IRPF acompanhando os índices de inflação, pois na medida em que a inflação se eleva e a atualização da tabela não acompanha esse crescimento na mesma proporção, o resultado é que o contribuinte pagará mais tributos do que o montante pago 
•• Tributação, direitos fundamentais e desenvolvimento

no ano anterior. Como a inflação reduz o poder de compra, não se pode admitir que a cobrança dos tributos seja exigida mediante reajuste inferior ao índice oficial de inflação anual, pois desta forma, a cada ano o contribuinte terá seus rendimentos tributados à alíquota da faixa de renda superior, representando uma clara injustiça devido ao menor poder de compra de seus rendimentos que foram corroídos pela inflação.

O SINDIFISCO Nacional explica que:

Mais um ano se passa e a correção da Tabela do IR em 4,5\% encontra-se abaixo da inflação oficial medida pelo Índice de Preços ao Consumidor Amplo (IPCA), o qual foi de 5,91\% em 2013. Somente em 2013 a defasagem na correção da Tabela do IR foi de $1,35 \%$. A não correção da Tabela do IR pelo índice de inflação faz com que o contribuinte pague mais imposto de renda do que pagava no ano anterior. (SINDIFISCO NACIONAL, 2014, p. 4).

Mantida a política prevalecente desde 2007 de corrigir a Tabela do IR pelo centro da meta de inflação definida pelo Banco Central, a correção será sempre parcial e a defasagem crescerá pela diferença entre o IPCA efetivamente observado e a previsão do centro da meta. (ibidem, p. 5).

Para Evilásio Salvador:

A partir de 1996, a tabela do Imposto de Renda (IR) deixou de ser corrigida periodicamente e com isso milhares de trabalhadores de menor poder aquisitivo passaram a ser tributados na fonte. No período de 1996 a 2001, a tabela do Imposto de Renda Pessoa Física (IRPF) ficou congelada. Desde então ocorreram as seguintes correções: 17,5\%, em 2002; 10\%, em 2005; e, 8\% a partir de fevereiro deste ano. Esses reajustes são insuficientes para repor integralmente os efeitos da inflação no pagamento de IR, pois não refletem toda a inflação do período. A inflação de janeiro/1996 a janeiro/2006, apurada pelo Índice de Preço ao Consumidor Amplo (IPCA/IBGE), foi de $104,98 \%$. Descontando os reajustes já concedidos de 17,5\% (2002), de 10\% (2005) e de $8 \%$ (2006), a tabela do Imposto de Renda, ainda, precisaria ser corrigida em $46,84 \%$, em $1^{\circ}$ de fevereiro de 2006. (SALVADOR, [200-], p. 7).

O grande problema desse congelamento da tabela do IR é que a defasagem dos valores usados como base de cálculo para definição de alíquotas resulta em um limite muito baixo de isenção, reduzindo a faixa cuja alíquota é de $0 \%$ e atingindo assim as pessoas de mais baixa renda. A este respeito, Roberto Boccacio Piscitelli se manifesta:

As distorções provocadas pela falta de atualização dos valores da tabela, além do aumento da carga tributária individual (isto é, da relação entre o imposto pago e a remuneração recebida), apresenta duas agravantes, uma das quais resulta da própria progressividade da tabela (alíquotas crescentes para faixas crescentes de renda), que se 
verifica quando o indivíduo passa de uma faixa para outra ou - o que é pior - quando é incorporado à categoria de contribuinte por haver ultrapassado o limite de isenção. A outra consequência resulta da combinação da progressividade com o limite de isenção e faz com que a falta de atualização da tabela provoque um efeito ainda mais perverso: o aumento da carga é maior para os contribuintes situados nas faixas inferiores da tabela. Ou seja, se o congelamento da tabela é injusto e discriminatório para os assalariados, é ainda mais injusto e discriminatório para quem ganha menos! (Piscitelli, 2010, p. 56).

Ao atualizar o valor sem acompanhar o índice oficial de inflação, o governo faz com que o indivíduo se torne sujeito passivo do tributo e recolha o imposto pelo simples fato de seus rendimentos salariais terem sido reajustados de acordo com o índice inflacionário, pois com o aumento nominal do salário a cada ano acompanhando a inflação e a atualização da tabela com valor aquém, o indivíduo que até então se enquadrava na faixa de isenção, agora com rendimentos mais altos, passa a ser tributado na primeira faixa, e para aqueles que já contribuíam, incidirá a alíquota da faixa seguinte, o que demonstra claramente uma injustiça e desrespeito aos princípios da ordem fiscal, na medida em que não há um aumento real dos salários, mas apenas nominal, e que desta forma, o contribuinte terá reduzida a sua renda disponível.

SINDIFISCO também aponta que:

A correção da Tabela do IR pelo índice integral da inflação evitaria uma distorção comum na política tributária brasileira dos últimos 15 anos: o pagamento de mais imposto de renda, mesmo por aqueles que não tenham auferido ganhos reais. Esta é uma séria ofensa aos princípios da Capacidade Contributiva e da Progressividade, inscritos na Constituição Federal. A conjunção de ambos diz que quem ganha mais deve pagar progressivamente mais. Porém, a não correção integral da tabela faz com que muitos daqueles que não ganharam mais ou mesmo ganharam menos, paguem mais. É, portanto, uma política regressiva, desprovida de um senso maior de justiça fiscal e que, por estas razões, conduz à ampliação das desigualdades distributivas do País. (SINDIFISCO NACIONAL, 2010, p. 8)

A pesquisa do Sindifisco, que data de 2014, traz alguns dados numéricos, como por exemplo, prevê que para aquele ano a correção da tabela do IRPF de acordo com o índice oficial de inflação implicaria uma ampliação da faixa de isenção ao valor de $\mathrm{R} \$ 2.761,56$, o qual se mostra hoje, dois anos depois, ainda muito superior ao nosso atual limite. (ibidem, p. 10).

Neste sentido, Evilásio Salvador assevera que:

Em 1995, o limite de isenção da tabela do Imposto de Renda era equivalente a 10,48 salários mínimos. A falta de correção da tabela acabou transformando trabalhadores 
•• Tributação, direitos fundamentais e desenvolvimento

com renda acima de 3,9 salários mínimos em contribuintes do IR, ferindo o princípio da capacidade contributiva estabelecido na Constituição Federal. (SALVADOR, [200-], p. 7).

Os estudos evidenciam, portanto, que as alterações da tabela do IRPF não acompanham o aumento expressivo do índice inflacionário ao longo dos anos. A consequência deste congelamento, em que as faixas de tributação aumentam desproporcionalmente aos índices oficiais de inflação, os quais por sua vez corroem os salários e proventos, diminuindo o poder de compra do contribuinte, é o aumento da arrecadação tributária. O grande problema é que este aumento de receita aos cofres públicos não tem por origem a tributação sobre a população de classes mais altas, pelo contrário, é fruto de uma alta carga tributária imposta aos assalariados.

Conforme exposto anteriormente, a desatualização da tabela faz com que o IR apresente hoje um valor de isenção muito abaixo do que se considera justo. Com isso, aumenta-se a incidência do tributo, na medida em que passa a ser cobrado de uma parcela da população que originariamente não deveria recolhê-lo. A inclusão destes sujeitos ao quadro de contribuintes, desrespeitando claramente o Princípio da Capacidade Contributiva, gera uma tributação inconstitucional, tendo em vista que os princípios possuem força normativa, e até mesmo uma tributação ilegal.

Para além da Capacidade Contributiva, sabe-se que a atuação fiscal deve obedecer a outros princípios constitucionais, como o da garantia ao mínimo existencial, vedação ao confisco e preservação da dignidade humana. Neste contexto, é possível afirmar que um limite de isenção desatualizado e, por consequência, injusto, faz com que a cobrança do IR recaia também sobre os mais pobres, que apesar de não apresentarem capacidade de contribuir, ou mesmo sinais demonstrativos de riqueza, tornar-se-ão sujeitos da obrigação tributária. Esta incidência tributária pode impactar de tal forma a vida do contribuinte, que tem seu salário comprometido com gastos ordinários e essenciais, a ponto de prejudicar-lhe a garantia do que se considera mínimo à existência. Com isso, tem-se um duplo desrespeito, pois a cobrança do Imposto desobedece ao princípio do mínimo existencial, e ao mesmo tempo, deixa de observar o princípio da dignidade humana, tendo em vista que é impossível se cogitar uma existência digna diante de tal circunstância.

Em relação à vedação ao confisco, o objetivo da Carta Magna é impedir uma atuação estatal na vida do indivíduo que afete gravemente seu patrimônio ou seus rendimentos, ou seja, não se deve permitir que o Fisco intervenha na propriedade privada do indivíduo para satisfazer suas necessidades. Como se vê, esta proteção 
não é garantida na situação em análise, visto que a cobrança do imposto aos assalariados, que muitas vezes percebem renda muito próximo ao valor do limite isenção do tributo, compromete os seus rendimentos com o pagamento da prestação.

Sendo assim, faz-se necessária uma justa atualização e correção do valor isentivo do IRPF como medida necessária para se efetivar os princípios da Capacidade Contributiva, garantia ao mínimo existencial, dignidade humana, e como meio de evitar o confisco.

\subsection{Iniciativas em trâmite no judiciário}

O Brasil vivencia hoje um cenário de crise econômica e política que influencia diretamente a vida dos cidadãos brasileiros, o que ocorre de forma ainda mais intensa na vida das pessoas que compóem a chamada classe baixa e média da sociedade. As pessoas com menor poder aquisitivo são as que mais sofrem diante dos desmandos governamentais e a alta carga tributária que lhes são impostas é a grande comprovação deste quadro problemático.

Há muito se discute a questão da Reforma Tributária como meio de reconduzir a atuação fiscal, tornando-a mais eficiente. Outro alvo de grande discussão é o reajuste da tabela de valores do IRPF, que deve realizar uma justa atualização das faixas e corrigir, principalmente, a correspondente à isenção, até mesmo como meio de se iniciar a tão almejada Reforma Tributária.

Conforme visto, o congelamento da tabela é uma situação de extremo desrespeito aos preceitos constitucionais e que assola predominantemente o segmento social com maior fragilidade econômica. Embora haja um grande debate em torno do assunto e o reajuste da tabela seja uma necessidade veemente, são muito tímidas as manifestações políticas ou legislativas neste sentido, como se pode observar adiante.

No ano de 2014, o Conselho Federal da Ordem dos Advogados do Brasil $(\mathrm{OAB})$ ingressou com uma Ação Direta de Inconstitucionalidade no STF questionando a correção da tabela de tributação do IRPF. A ADI n. 5096 apresenta histórico da legislação referente ao IR e demonstra que a correção da tabela não acompanha o percentual de inflação, e com isso, demonstra grande violação à Constituição. A ação pede que correção da tabela acompanhe o índice real de inflação e não as metas definidas pelo governo. De acordo com a proposta veiculada pela OAB, a tabela do IRPF, para o ano de 2014, deveria trazer como faixa de 
•• Tributação, direitos fundamentais e desenvolvimento

isenção o limite de $\mathrm{R} \$ 2.758,46$. $\mathrm{O}$ andamento processual aponta o pedido de ingresso da Federação Nacional das Empresas de Serviços Contábeis e das Empresas de Assessoramente, Perícias, Informaçoos e Pesquisas (FENACON- entidade sindical de segundo grau) e da Federação interestadual de trabalhadores engenheiros (FISENGE - criada por onze Sindicatos de Engenheiros e filiada à CUT) como Amicus curiae. Ademais, informa que os autos foram encaminhados ao relator para conclusão no mês de setembro deste ano.

No início do ano, a bancada de deputados do PT (Partidos dos Trabalhadores) apresentou um documento com propostas econômicas ao governo federal, que recebeu o nome de "Agenda para a retomada do desenvolvimento econômico com justiça social", sendo a primeira parte composta por medidas de alteração na estrutura tributária com o objetivo de ampliar a arrecadação, tributando mais aquele que possui maior rendimento, ao invés de sobrecarregar os mais pobres. $\mathrm{Na}$ busca por um ajuste que garanta a justiça tributária, o projeto visava algumas mudanças na tabela do IR, dentre elas, a que interessa saber é o reajuste da parcela de renda isenta de tributação que seria ampliada para o valor de $\mathrm{R}$ \$3.390, 00.

No dia $1^{\circ}$ de maio foi anunciado pela então presidenta Dilma Roussef um reajuste de 5\% na tabela do IR, que também ampliaria o valor de isenção, neste caso para $\mathrm{R} \$ 1.999,18$. Apesar de não representar um aumento significativo, também beneficiaria grande parte da população brasileira.

Além dessas iniciativas, existe uma campanha promovida pelo Sindifisco Nacional chamada de "Imposto Justo", cujo projeto de lei é de 2013, e tem por finalidade recolher assinatura popular. $\mathrm{O}$ projeto visa à correção da tabela do IR, reajustando o valor de isenção ao que se considera justo. O Sindifisco disponibiliza uma cartilha que explica as razões de tal medida e os benefícios advindos da atualização, promovendo a conscientização e buscando a adesão daqueles que têm acesso.

\section{CONCLUSÃO}

O Princípio da Capacidade Contributiva mantém convivência harmoniosa com diversos outros princípios constitucionais, dentre eles, o de maior relevância e pertinência temática diz respeito ao princípio da igualdade, cujo objetivo é assegurar o tratamento igual a toda coletividade de pessoas. Busca-se assegurar a igualdade material e não apenas formal, no sentido de que o Estado deve observar as circunstâncias e peculiaridades presentes nos diferentes níveis sociais. Esta igualdade, 
também conhecida por isonomia, faz com que os iguais sejam tratados da mesma forma, mas que os desiguais sejam tratados de maneira diferente, na medida de suas desigualdades. A isonomia pretende direcionar a atuação fiscal para que a tributação sobre as diferentes classes sociais possa gerar impactos de mesma proporção.

A comunicação direta entre o Princípio da Capacidade Contributiva com o princípio da igualdade reside no fato de que este último orienta que a tributação só deve incidir quando houver efetivos sinais de riqueza, não basta que o sujeito tenha capacidade econômica, é preciso que ele apresente a real capacidade de contribuir com o fisco, sem que isto lhe afete as despesas necessárias à sobrevivência. Se o Estado não observa o poder de contribuir do indivíduo, sua atuação desrespeita também o princípio da igualdade, visto que estará assolando de forma mais rigorosa uma parcela da sociedade. Portanto, a Constituição estabelece como um dos princípios da ordem fiscal o da Capacidade Contributiva, com a finalidade de realizar uma distribuição justa do encargo financeiro, o que, por conseguinte, gera a observância de outros princípios, como o da garantia do mínimo existencial, em que o sujeito consegue ter acesso ao que se considera mínimo à sobrevivência. Além deste, garante-se a vedação de tributos com efeitos confiscatórios, pois o Fisco não pode interferir no direito de propriedade, e por fim, há também a defesa da dignidade humana, na medida em que são respeitados os direitos individuais.

O Princípio da Capacidade Contributiva é considerado um limite ao poder de tributar, principalmente no que diz respeito aos impostos, lembrando a menção expressa que a própria $\mathrm{CF}$ traz em seu art. $145, \$ 1^{\circ}$, a dizer que os impostos devem ser graduados segundo a capacidade econômica do sujeito. Com isso, torna-se claro que o Imposto de Renda, por sua característica de ser tributo direto, capaz de identificar o sujeito passivo e, consequentemente, sua condição econômico-financeira, é um dos impostos que mais realiza o Princípio da Capacidade Contributiva.

A tributação sobre a renda deve levar em consideração a capacidade de contribuir que cada indivíduo apresenta em relação às despesas públicas, tanto é verdade que as alíquotas são variáveis de acordo a faixa de renda percebida pelo indivíduo: à medida que se aufere maior renda, recolhe-se o imposto com alíquotas que crescem progressivamente. A cobrança do Imposto de Renda Pessoa Física realizada deste modo gera uma contribuição proporcionalmente maior daquelas pessoas que apresentam uma maior aptidão para gerar renda, sendo assim, há o respeito à isonomia tributária e garantia de justiça. 
-. Tributação, direitos fundamentais e desenvolvimento

Porém, ao analisar a atual tabela de valores do IRPF é possível constatar que, na prática, não se consagram tais preceitos constitucionais. As faixas representam as bases de cálculos com valores congelados, isto é, desatualizados. Neste contexto, merece destaque o valor correspondente à faixa de isenção, que no atual momento equivale a pouco mais de dois salários mínimos. Como a atualização da tabela não acompanha os índices oficiais de inflação, os efeitos são sentidos cada vez mais pelas classes sociais mais pobres, tendo em vista que a moeda é desvalorizada. Com isto, o sujeito que anteriormente não era obrigado a contribuir com a arrecadação estatal por falta de Capacidade Contributiva, além de sofrer uma diminuição do poder compra, decorrente da inflação, agora se torna sujeito passivo da obrigação, pois sua nova renda passa a enquadrá-lo na primeira faixa de tributação, ou até mesmo quem já contribuía e acaba mudando para a faixa seguinte.

Como se pode notar, a condição de contribuinte, neste caso, não respeita o Princípio da Capacidade Contributiva, afinal, o aumento dos seus rendimentos se deu apenas nominalmente, não se considera um aumento real. Logo, não há que se dizer que a tributação é justa. Por fim, considera-se de fundamental importância à busca do ideal de justiça tributária que a cobrança do IR respeite os limites constitucionais e que, portanto, seja realizada uma correção do valor isentivo da tabela do IRPF, de modo a diminuir os impactos dessa defasagem sobre os mais pobres, respeitando a assertiva de que só poder haver tributação diante de efetivos signos de riqueza.

\section{REFERÊNCIAS}

BRASIL. Constituição (1988). Constituição da República Federativa do Brasil. Brasília, Distrito Federal: Senado, 1988.

BRASIL. Lei n. 5.172 de 25 de outubro de 1966. Código Tributário Nacional. Brasília, Distrito Federal: Congresso Nacional, 1966.

BRASIL. Medida Provisória n. 598 de 31 de agosto de 1994. Brasília, Distrito Federal: Congresso Nacional, 1994.

BRASIL. Superior Tribunal Federal. Ação Direta de Inconstitucionalidade n. 5096. Brasília, Distrito Federa/l, 2014.

CARVALHOS, Paulo de Barros. Curso de direito tributário. 26. ed. São Paulo: Saraiva, 2015.

CASSONE, Vittorio. Direito tributário. 22. ed. São Paulo: Atlas, 2011. 
CASTRO, Fábio Avila de. Imposto de renda da pessoa física: comparações internacionais, medidas de progressividade e redistribuição. Brasília, 2014. Dissertação (Mestrado em Economia) - Universidade de Brasília, 2014.

CORDEIRO, Rodrigo Alache. Princípios constitucionais tributários. Porto Alegre: Sergio Antonio Fabris, 2006.

FEITOSA, Raymundo Juliano; FRATTARI, Rafhael e LIMA, Renata Albuquerque. Direito Tributário e Financeiro I. Santa Catarina, 2015. CONPEDI, 2015.

FERREIRA, Abel Henrique. O principio da capacidade contributiva frente aos tributos vinculados e aos impostos reais e indiretos. [200-].

GADELHA, Gustavo de Paiva. Isenção tributária: crise de paradigma do federalismo fiscal cooperativo. Recife, 2006. Dissertação (Mestrado em Direito) - Faculdade de Direito do Recife, 2006.

GREGORIO, Argos Magno de Paula. A capacidade contributiva. São Paulo, 2007. Dissertação (Mestrado em Direito) - PUC/SP, 2007.

GUTIERREZ, Miguel Delgado. O imposto de renda e os principios da generalidade, da universalidade e da progressividade. São Paulo, 2009. Tese (Doutorado em Direito) - USP, 2009.

HACK, Érico. Princípio da capacidade contributiva: limites e critérios para o tributo. Rev. SJRJ, Rio de Janeiro, v. 21, n. 36, p. 83-94, abr. 2014.

HORN, Sérgio Vasconcellos. Análise do imposto sobre a renda segundo os princípios constitucionais tributários da universalidade, generalidade e progressividade. Porto Alegre, 2013. Monografia (Direito) - Universidade Federal do Rio Grande do Sul, 2013.

NOBRE JUNIOR, Edilson Pereira. Princípio constitucional da capacidade contributiva. Porto Alegre: Sergio Antonio Fabris, 2001.

PAULSEN, Leandro; MELO, José Eduardo Soares de. Impostos Federais, Estaduais e Municipais. 9. ed. Porto Alegre: Livraria do Advogado, 2015.

PISANI, Carolina Dorneles. O princípio da capacidade contributiva e os limites ao poder de tributar. Um caminho à concretização da justiça fiscal, 2010.

PISCITELLI, Roberto Boccaccio. A correção do imposto de renda. Cadernos ASLEGIS, Câmara dos Deputados, Brasília, 2010, n. 39, p. 48-53, jan./abr. 2010.

PT. Proposta de deputados petistas isenta de IR salários de até $R \$ 3.390$. Disponível em: $<$ http://www.pt.org.br/proposta-de-deputados-petistas-isenta-de-ir-salarios-deate-r-3-390/>. Acesso em: out. 2016.

PT. Reajuste do IR: entenda como a medida beneficiará trabalhador. Disponível em: $<$ http://www.pt.org.br/reajuste-do-ir-entenda-como-a-medida-beneficiara-trabalhador/>. Acesso em: out. 2016. 
•• Tributação, direitos fundamentais e desenvolvimento

RECEITA FEDERAL. Histórico da tabela de progressividade do IRPF. Brasil, 2016. Disponível em: <http://idg.receita.fazenda.gov.br/acesso-rapido/tributos/irpf-impostode-renda-pessoa-fisica>. Acesso em: out. 2016.

SALVADOR, Evilásio. A distribuição da carga tributária: quem paga a conta?, [200-].

SINDIFISCO NACIONAL. A defasagem na correção da tabela do imposto de renda pessoa física. Brasília, 2014.

SINDIFISCO NACIONAL. Imposto justo. Disponível em: <https://www. sindifisconacional.org.br/impostojusto/? saibamais=conheca-a-minuta-completa-doprojeto-de-lei>. Acesso em: out. 2016.

TORRES, Ricardo Lobo. Curso de direito financeiro e tributário. 18. ed. São Paulo: Renovar, 2011. 